\title{
EDUCATION AND TRAINING FOR LIBRARIANSHIP AND INFORMATION WORK: ANNUAL BIBLIOGRAPHY, 1988
}

\author{
Alan J. CLARK \\ Department of Information and Library Studies Library, University College of Wales, Aberystwyth, \\ Llanbadarn Fawr, Aberystwyth, Dyfed SY23 3AS, UK
}

Received 5 June 1989

This is the third year of this annual bibliography of work in librarianship and information science education and training. The bibliography covers works published in 1988 and is international in scope.

The arrangement is by subject and then alphabetical by author or title, with a contents list facilitating broad subject access. The name index includes authors and name subject entries for individuals, organizations and some other entities. The alphabetical subject index includes entries for names of countries and regions. A list of periodical title abbreviations used is also supplied.

As in previous years, compilation of the bibliography has used in the main the collections and resources of the library of the College of Librarianship Wales. 1988 marks the twenty-fifth anniversary of the founding of the College and also the start of a new era in its life. By the time this bibliography is published, in fact as of August 1, 1989, the College will have merged with the University College of Wales, Aberystwyth. This represents the culmination of a process of gradual strengthening of the relationship between the two institutions which has been taking place over a number of years. CLW will be the Department of Information and Library Studies of the University. It will also be one of the largest departments in the University. CLW Library, which has a collection of international stature in its subject field, will continue to serve the teaching and research needs of the Department, as its Departmental Library, and will play an important role in its teaching programmes. It will also continue to provide library facilities and information services for library and information professionals within Wales and beyond. 


\section{CONTENTS}

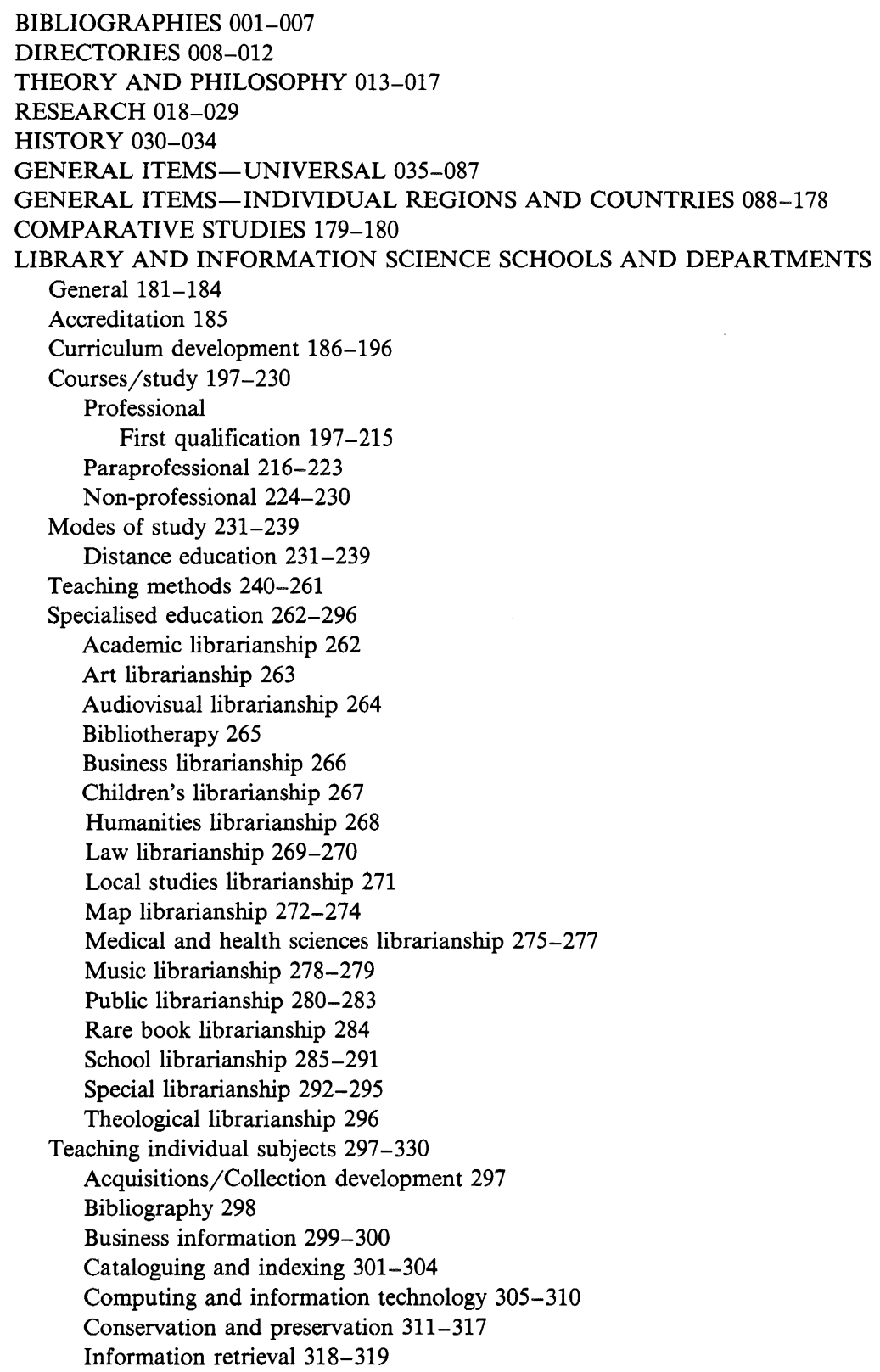


Intellectual property 320

Management 321-325

Marketing 326

Reference and information service 327-328

Systems analysis 329

User education 330

Practical work experience 331-335

Teaching staff / Faculty 336-349

Students $350-360$

Individual schools $361-373$

PROFESSIONAL QUALIFICATIONS 374-385

CAREER DEVELOPMENT 386-408

CONTINUING EDUCATION 409-435

TRAINING 436-488

General 436-444

Specialised 445-488

ROLE OF ASSOCIATIONS AND SOCIETIES IN LIBRARY EDUCATION 489-492

EDUCATION AND TRAINING FOR RELATED OCCUPATIONS 493-526

EMPLOYMENT MARKETPLACE 527-564

NAME INDEX

SUBJECT INDEX

LIST OF PERIODICAL TITLE ABBREVIATIONS 


\section{ANNUAL BIBLIOGRAPHY, 1988}

\section{BIBLIOGRAPHIES}

001. Clark, Alan J. Education and training for librarianship and information work: annual bibliography, 1987. Education for Information 6(3) 1988 257-314.

002. Diplomoppgaver ved Statens bibliotekhøgskole 1988. Synopsis 19(4) 1988217.

003. Hovedoppgaver ved Statens bibliotekhøgskole 1987. Synopsis 19(3) 1988 159-162.

004. MOORE, Nick. The new information professions. British Book News Mar. 1988 164-165, 167.

005. Parmer, Coleen, Paraprofessionals in the literature: a selective bibliography. J. Educ. Lib. \& Inf. Sci. 28(4) Spring 1988 249-251.

006. Schwarz, Stephan and FerligoJ, A. Curriculum development on quantative methods in library management: a bibliography. In N. Tudor-Silovic \& I. Mihel, eds. Information research: research methods in library and information science. London: Taylor Graham, 1988. ISBN 094756826 3. pp. 166-173.

007. TAMEeM, Jamal A. Saudi Arabian librarianship: an annotated bibliography (1950-1986). Int. Lib. Rev. 20(4) 1988 495-507.

\section{DIRECTORIES}

008. Accredited library schools. In Bowker annual of library and book trade information. 33rd ed. New York: Bowker, 1988. ISBN 083522468 6. pp. 316-319.

009. Courses in library and information science 1988-89. [S.1.]: Library Association of Australia, [1988].

010. Library scholarship and award recipients. In Bowker annual of library and book trade information. 33rd ed. New York: Bowker, 1988. ISBN 083522468 6. pp. 322-332.

011. Library scholarship sources. In Bowker annual of library and book trade information. 33rd ed. New York: Bowker, 1988. ISBN 083522468 6. pp. 319-322.

012. Professional calendar: forthcoming courses and conferences for the library and information profession. Aberystwyth: College of Librarianship Wales, 1988. 


\section{THEORY AND PHILOSOPHY}

013. AL-HAJRASY, Sa'ad. Libraries and information science as an academic field of speciality. [In Arabic] Maktabat Al-Idarah 15(3) 1988.

014. Houser, Lloyd. A conceptual analysis of information science. Lib. \& Inf. Sci. Res. 10(1) 1988 3-34.

015. JÄrVElin, Kalervo and VAKKari, Pertti. Kirjasttiede ja informatiikka-tiedon hankinnan tiede. Kirjastotoiede ja Informatiikka 7(1) 1988 18-32.

016. SABLE, Martin H. Library science instruction: a credo. Int. Lib. Rev. 20(2) 1988 $135-167$.

017. Savolainen, Reijo. Ongelmana omakuva-kirjastotieteen ja informatiikan tutkimuskohteen tematisointia. Kirjastotiede ja Informatiikka 7(1) 1988 10-17.

\section{RESEARCH}

018. BenEDIKTSSON, Daniel. LIS research in Iceland: a review of past and present. Scand. Pub. Lib. Q. 21(3) 21-24.

019. DeVarajan, G. Recent trends at postgraduate level researches in library and information science in India. Lucknow Librarian 20(1) 1988 26-32.

020. EAST, Harry. Funded research in the United Kingdom. Part 1: Sources and distribution of grants. Lib. Ass. Rec. 90(1) 1988 29-30.

021. East, Harry. Funded research in the United Kingdom. Part 2: The pursuit of grants. Lib. Ass. Rec. 90(2) 1988 101-102.

022. HeINe, Mike. Research in the Department of Librarianship and Information Studies, Newcastle upon Tyne Polytechnic. Lib. \& Inf. Res. News 11(41) 1988 8-12.

023. HILL, Michael W. Involvement in research and development. In N.T. Silovic and I. Mihel, eds. Information research: research methods in library and information science. London: Taylor Graham, 1988. ISBN 094756826 3. pp. 43-45.

024. KORYTNYK, Christine A. Comparison of the publishing patterns between men and women PhDs in librarianship. Library Quarterly 58(1) 1988 52-65.

025. Latham, Sheila. The search for research [Editorial]. Canadian Library Journal 45(6) 1988 345-346.

026. LeIDE, John E. Research. In ALA Yearbook of library and information services. Chicago: American Library Association, 1988. ISBN 083890489 0. pp. 284-293.

027. MOORE, Nick. Research. In D.W. Bromley and A.M. Allott, eds. British librarianship and information work 1981-1985. Vol. 1. London: Library Association, 1988. ISBN 085365557 X. pp. 274-283. 
028. Tejomurty, A. Dissertations of Master of Library Science: a case study. Herald of Library Science 27(3-4) 1988 192-195.

029. White, Brenda. The impact of British Library R and D Department publications on the operational management of libraries. London: British Library; Edinburgh: Brenda White Associates, 1988 (British Library Research and Development Department report, no. 5963).

\section{HISTORY}

030. KaUla, P.N. Hundred years of library and information science education. Herald of Library Science 27(3-4) 1988 170-177.

031. MrksA, Francis L. The Columbia School of Library Economy, 1887-1888. Libraries and Culture 23(3) 1988 249-280.

032. MUNTHE, Gerhard. Forgjengere og foregangsmenn. 6. Melvil Dewey. Synopsis 19(3) 1988 119-122.

033. PASSET, Joanne Ellen, 'The Open Door of Opportunity': the Indiana Library School and its students, 1905-1912. Libraries and Culture 23(4) 1988 474-492.

034. World's first library school celebrates centennial. Library Journal 113(1) 1988 16.

\section{GENERAL ITEMS-UNIVERSAL}

035. Ad Hoc Committee on Education and Training [Policy and Programme of the General Information Programme] report on sixth session, January 1988, Paris. Unisist Newsletter 16(3) 1988 48-50.

036. AliRe, Camila, ed. Education for library personnel. Colorado Libraries 14(3) 1988 8-26.

037. AMAN, Mohammed M. IFLA Section of Library Education and Training: 1987 report. J. Educ. Lib. \& Inf. Sci. 28(3) 1988 234-237.

038. Australian Libraries Summit 1988. Resolutions: education for library and information services. ACLIS News 1(2) 1988 [Unpaginated].

039. Bellardo, Trudi. Options and trends in the training of information professionals. J. Amer. Soc. Inf. Sci. 39(5) 1988 348-350.

040. Corbin, John. The education of librarians in an age of information technology. J. Lib. Admin. 9(4) 1988 77-87.

041. CoRDonier, Jacques. Du pont au ressort: théorie et pratique dans l'enseignement des sciences de l'information. Documentaliste 25(6) 1988 275-277. 
042. Courrier, Yves. Harmonization of education and training: theoretical and practical reflections. IFLA Journal 14(3) 1988 231-237.

043. Courrier, Yves. Prévisions quantatives et qualitatives et information des spécialistes de l'information documentaires. Libri 38(1) 1988 1-25.

044. Cronin, Blaise. Bringing education for information workers into the 1980s. Aslib Information 16(2) 198839.

045. CRONIN, Blaise. New horizons for the information profession: strategic intelligence and competitive advantage. In H. Dyer and G. Tseng, eds. New horizons for the information profession. London: Taylor Graham, 1988. ISBN 094756832 8. pp. $3-22$.

046. De Faunce, Maria Casas. La información frente al desajio del año 2000: recursos humanos en la información respuesta al desajio. Revista AIBDA 9(1) 1988 $1-15$.

047. Dosa, Marta L. and Froelich, Thomas J., eds. Education and training for technology transfer: papers presented at the FID Education and Training Committee Workshop, Montreal, 8-11 Sept. 1986. The Hague: FID, 1988. ISBN 9266 $00670 \mathrm{X}$ (FID publication, no. 670).

048. Dosa, Marta L. Has international education been politicized? J. Amer. Soc. Inf. Sci. 39(5) 1988 351-354.

049. Dosa, Marta L. and Froelich, Thomas J. Report for 1987-1988 [FID Education and Training Committee] FID News Bulletin 38(9) 1988 61-63.

050. Dosa, Marta L. Some issues pertaining to information education and policies. Lib. Sci. Slant Doc. 25(4) 1988 193-214.

051. Garrison, Guy. Challenges to information science education. J. Amer. Soc. Inf. Sci. 39(5) 1988 362-366.

052. Gorman, G.E. Teaching library science: aspects of effectiveness in academic life. Libri 38(4) 1988 297-313.

053. Greguletz, Alexander. Die Bibliothekswissenschaft und die Informationsund Kommunikationstechnologien: eine Betrachtung zur Hochschulausbildung. Zent. Bib. 102(7) 1988 290-298.

054. HAAs, Warren J. Information studies, librarianship. Bull. Med. Lib. Ass. 76(1) $19881-6$.

055. HAYES, Robert M. Education of the information professional: a library school perspective. J. Amer. Soc. Inf. Sci. 39(5) 1988 312-317.

056. HoRTON, Forest Woody Jr. Library and information resources management. Aslib Information 16(2) 1988 43-44.

057. HURD, Julie M. Technology: an agent for change in education for information science. J. Amer. Soc. Inf. Sci. 39(5) 1988 323-326. 
058. International Federation of Library Associations. Education and Research [Division]: annual report 1986/87. In IFLA Annual 1987. Saur: München; London, 1988. ISBN 359820668 2. p. 102.

059. Johnson, Ian M. IFLA Section on Education and Training. Training and Education 5(2) 1988 39-43.

060. JONES, Derek. Education and training. In D.W. Bromley and A.M. Allott, eds. British librarianship and information work 1981-1985. Vol. 1. London: Library Association, 1988. ISBN 085365557 X. pp. 230-258.

061. Kafgbein, Paul. La Division de la Formation et de la Recherche de l'IFLA 1977-1987. Documentation et bibliothèques 34(1) 1988 33-35.

062. KAEgBeIN, Paul. Ten years of the Division of Education and Research. IFLA Journal 14(1) 1988 57-61.

063. KaEGBein, Paul. Zehn Jahre IFLA-Abteilung Ausbildung und Forschung. Zen. Bib. 102(3) 1988 123-126.

064. Kawatra, P.S. Design of learning experiences in library and information science education. Lucknow Librarian 20(1) 1988 23-25.

065. Le CoAdic, Yves. L'évolution des métiers de la communication de l'ist à l'étranger. Documentaliste 25(1) 1988 23-24.

066. Lendvay, Olga. Disponsibilidad y apoyo de la formación en el campo de información para paises en desarrollo. Revista AIBDA 9(1) 1988 43-54.

067. LewIS, Denis. Information management: the way ahead. Aslib Information 16(2) 198837.

068. Lunin, Lois F. and Cooper, Marianne, eds. Perspectives on education of the information professional: new dimensions, new directions. J. Amer. Soc. Inf. Sci. 39(5) 1988 307-365.

069. MCGARRY, Kevin. Education for the world of information: some glimpses of the future. Assignation 6(1) 1988 34-36.

070. MCKeE, Bob. Information management and library/information studies: fusion, diffusion, confusion? Training and Education 5(2) 1988 31-38.

071. Meadows, A.T. Future trends in information science education. In P.A. Yates-Mercer, ed. Future trends in information science and technology. London: Taylor Graham, 1988. ISBN 094756820 4. pp. 105-114.

072. Moore, Nick. New information professionals. Aslib Information 16(2) 1988 $40-41$.

073. RocheSTER, Maxine K. Preparing librarians for the 21st century: study abroad. IFLA Journal 14(1) 1988 29-39. 
074. Rolland-Thomas, Paule. Les relations avec les autorités: leur intégration dans la formation professionelle universitaire des bibliothècaires, archivistes, et autres responsables des services d'information. In Procs. IFLA General Conference, 54th, Sydney, 1988 (Paper 53 TRAIN F).

075. ScotT, Elspeth J. The future of information science as a profession. In P.A. Yates-Mercer, ed. Future trends in information science and technology. London: Taylor Graham, 1988. ISBN 094756820 4. pp. 74-90.

076. Seibel, Bernadette. Au nom du livre: analyse sociale d'une profession: les bibliothècaires. Paris: Documentation Française, 1988. ISBN 2110019379.

077. SHELDON, Brooke E. On beyond management: leadership and the information professions. In ALA Yearbook of library and information services. Vol. 13. Chicago: American Library Association, 1988. ISBN 083890489 0. pp. 8-10.

078. SIPPINGS, Gwenda. Library and information resources management [Editorial]. Aslib Information 16(2) 198836.

079. TeES, Miriam H. ed. Education and research in library and information science in the information age: means of modern technology and management. Procs. IFLA/China Society of Library Science Seminar, Beijing, 1986. München; London: Saur, 1988. ISBN 3598217730 (IFLA publications, no. 43).

080. TeEs, Miriam H. Harmonization of education and training programmes for library, information and archive personnel: a report of the Colloquium held in London 9-15 August 1987. IFLA journal 14(3) 1988 243-246.

081. WalczaK, Marian. Perspektywa ksztalcenia bibliotekarzy do końca stulecia. Bibliotekarz 55(7/8) 1988 3-7.

082. WALES, John. Doomsday or resurrection-professional information management and the management of information professionals. Aslib Proceedings 40(7/8) 1988 213-216.

083. WeRnER, Rosemarie. Perspektivische Aufgabenstellungen in Aus- und Weiterbildung von Bibliotheks- und Informationsfachkadern. Zen. Bib. 102(1) 1988 1-8.

084. Where is our niche? [Editorial]. Assistant Librarian 81(3) 1988 33-34.

085. Wirson, Pauline. Mission and information: what business are we in? J. Acad. Lib. 14(2) 1988 82-86.

086. WILson, Tom. Information management: a new focus for integration? IFLA Journal 14(3) 1988 238-242.

087. YockLUNN, John. The barefoot librarian: a model for developing countries? Libraries alone 1(1) 1988 13-20. 


\title{
GENERAL ITEMS-INDIVIDUAL REGIONS AND COUNTRIES
}

\author{
Algeria
}

088. Boumarafi, B.B. and HaYTHORNTHWAITE, J. Library/information education in Algeria. Int. Lib. Rev. 20(4) 1988 469-475.

Arab countries

089. AlqudSI-GhabRA, T. Librarianship in the Arab World. Int. Lib. Rev. 20(2) 1988 233-245.

Asia

090. Chaudhry, Abdus Sattar. Information science curricula in graduate library schools in Asia. Int. Lib. Rev. 20(2) 1988 185-202.

Australasia

091. Education for librarianship in Australasia: a review. Educ. Lib. Aust. 5(2) 1988 47-132.

Australia

092. Beattie, Kathleen. Principles for a national information policy: technological politics and education. Educ. Lib. Aust. 5(1) 1988 5-9.

093. BROAdBENT, Marianne. After the beginning: post-initial library and information management education in Australia. Educ. Lib. Aust. 5(2) 1988 48-53.

094. BROADBENT, Marianne. Education for information and library services: patterns, paradigms and programs. Aust. Acad. \& Res. Lib. 19(3) 1988 145-160.

095. RAYWARD, W. Boyd. Education for librarianship in Australia: some current issues. Educ. Lib. Aust. 5(2) 1988 55-58.

096. ReID-Smith, Edward R. Australia, IFLA and education for librarianship. Educ. Lib. Aust. 5(2) 1988 124-132.

097. SANDERS, Roy. Education for rural librarianship in Australia. Educ. Lib. Aust. 5(2) 1988 87-92.

\section{Belize}

098. HULSE, Robert. Library education in Belize [1988 Summer Programme on Basic Library Science, Belize City, 1-12 August]. COMLA Newsletter No. 6219884. 


\section{Botswana}

099. GibBons, Frank. Education and training to meet the needs of a changing library and information environment. Information Trends-News Magazine 1(1) $198822-27$.

100. Havard-Williams, Peter. A blueprint for development-library studies in Botswana. Information Trends-News Magazine 1(2) 1988 70-75.

\section{Brazil}

101. De Figueiredo, N.M. and Menou, M.J. Assessing needs for teaching and information science in Brazil. J. Educ. Lib. \& Inf. Sci. 28(3) 1988 188-200.

\section{Brunei}

102. Francis, Simon. Continuing professional education needs for Brunei Darusalam: the search for quality. In Procs. IFLA General Conference, 54th, Sydney, 1988 (Paper 110-RTCPE-3-E).

\section{Canada}

103. Bewley, Lois. Parting thoughts and shots. [Education column]. Canadian Library Journal 45(1) 1988 10-11.

104. HowARD, Helen. Library and information studies programs in Canada. Library Times International 5(2) 198820.

\section{China, People's Republic}

105. LI, Chang Quing. Trends and problems of library and information science education in China. [In Japanese]. Ann. Jap. Soc. Lib. Sci. 34(3) 1988 whole issue.

106. PindLowA, Wanda. Ksztalcenie kadr gla słuzb informacji naukowej w Chińskiej Republice Ludowej. Poradnik bibliotekarza 1988 (1-2) 10-13.

\section{Czechoslovakia}

107. BAČUvČıKovÁ, Jitka. Seminar pedagogických pracovniko střednich knihovnicky̌ch škol a 35 výroči vzniku SKS v Brne. Techniká Knihovna 32(1) 1988 25-26.

108. VodıČKovÁ, Hana. Inovovaný učebni plán studia vedekých informací a knihovnictví na filozofických fakultách. Techniká Knihovna 32(4) 1988 97-101. 
Denmark

109. WestLey, David Donald. Education for library and information work in Denmark. MA Thesis, Loughborough University of Technology, 1988.

Europe

110. Bowden, Russell. MeIlleur ten years on: implementation of the report. Outlook on Research Libraries 10(11) 1988 2-6.

\section{Finland}

111. LAAKsovirTa, Tuula. Koulutuksen kahdeksan vuosikymmentä. Kirjastolehti 81(9) 1988 388-391.

112. VeRHO, Seppo. Koska työvoimapula loppuu? Kirjastolehti 81(9) 1988 382-383.

113. VUORIA, Risto. Pätevöitymiskoloutus on väliakaista. Kirjastolehti 81(9) 1988 385-386.

\section{Germany, Democratic Republic}

114. FischbaCH, Gerda. Forscher und Fachinformatoren in der organisierten Zusammenarbeit: eine Untersuchung aus den Gesellschaftswissenschaften. Informatik 35(2) 1988 72-75.

115. HolsTE-FlinSPACH, Karen. Ausbildung für eine mittlere beruflicher Ebene in öffentlichen Bibliotheken der DDR UND BRD. Bibliotheksdienst 22(1) 1988 12-21.

116. WeRner, Rosemarie. Präzisierte Fachschulausbildung für Bibliothekare. Zen. Bib. 102(1) 1988 17-18.

\section{India}

117. Bansal, G.C. and TIKKU, U.K. Library science education in Panjab. Int. Lib. Rev. 20(3) 1988 395-403.

118. KumAR, P.S.G. Hundred years of library education and its future. Herald of Library Science 27(1-2) 1988 81-89.

119. KUMAR, P.S.G. Modernization vis-à-vis library and information science education in India. In C.P. Vashishth, ed. Modernisation in libraries. Seminar Papers, 33rd All India Library Conference, 1987. Delhi: Indian Library Association, 1988. ISBN 818521618 5. pp. 159-164.

\section{Iran}

120. HARIRI, Mehrangiz and HUSSEIN, Davoodijar. Continuing library/information 
science education in Iran. The assessment of IRANDOC short courses (1982-1986). Int. Lib. Rev. 20(1) 1988 19-28.

Italy

121. Bellingeri, Luca and Sebastiani, Marco. Il primo corso di rechtamento per bibliotecari: luci e ombre di un esperimento. AIB Boll. Inf. 28(1-2) 1988 93-96.

122. CAProni, Attilio Mauro. Contributo per una storia della formazione professionale dei bibliotecari in Italia. AIB Boll. Inf. 28(1-2) 3-36.

123. Curricula formativi i una proposta di standards. AIB Boll. Inf. 28(1-2) 1988 $41-50$.

124. Le regioni. AIB Boll. Inf. 28(1-2) 1988 97-116.

Japan

125. ToRIo, Miwako. Documents of a movement for the promotion of school status to University of Library and Information Science. [In Japanese]. Ann. Jap. Soc. Lib. Sci. 34(2) 1988 87-91.

\section{Jordan}

126. AJlounI, Thair. JLA training courses and membership during 25 years (1963-1988). [In Arabic]. Rissalat al Maktaba 23(4) 1988.

\section{Malawi}

127. Msiska, Augustine W.C. Malawian librarianship looks to the future. Training and Education 5(2) 1988 44-48.

\section{Netherlands}

128. Aelberts-Van De Ven, Dule C.A. Met kunst- en vliegwerk: balance van een jaar post HBO. Open 20(5) 1988 172-176.

129. FARROW, Catherine. Library and information science education in the Netherlands: the undergraduate programme. Education for Information 6(2) 1988 199-209.

New Zealand

130. Biculturalism and library education in New Zealand. COMLA Newsletter No. 6219886.

131. Johnston, Stuart. Education for librarianship. New Zealand Libraries 45(10) 1988 226-230. 
132. Na Te Ropu Takawaenga (Bridgebuilders Collective). Libraries and biculturalism and Submission to the Joint Advisory Committee on the Proposed Course Prescription for the Diploma in Librarianship 1990 (JACL). Library Life $11619881,3$.

133. RonNie, Mary A. An evaluation of education for librarianship in New Zealand: the Saunders report. New Zealand Libraries 45(9) 1988 194-196.

134. Saunders advice heeded. Library Life 12019886.

135. SAUNDERS, Wilf. An evaluation of education for librarianship in New Zealand. Educ. Lib. Aust. 5(2) 1988 59-69.

Nicaragua

136. BLOCH, T. and ACEVEDo, A. Library education in revolutionary Nicaragua. J. Educ. Lib. \& Inf. Sci. 28(3) 1988 169-176.

Nigeria

137. OchоGWU, M.G. Issues in education for librarianship in Nigeria. Training and Education 5(3) 1988 64-71.

138. NzotTA, Briggs C. Research and education for research in Nigerian library schools. Education for Information 6(2) 1988 123-143.

Norway

139. AlNaes, T. Library and information science education in Norway. Education for Information 6(2) 1988 187-197.

140. Bibliotekutdanning. Synopsis 19(5) 1988240.

141. HANSEn, Kjell Birger. Behøver vi flere bibliotekarer-Kanskje det er 'informatikere' vi trenger? Synopsis 19(5) 1988 246-248.

142. KROKEN, Gunvor Thori. Library training for non-professional chief librarians. Scand. Pub. Lib. Q. 21(3) 1988 29-31.

143. RugaAs, Bendik. Verden og vu. Synopsis 19(2) 1988 53-54.

Papua New Guinea

144. Evans, John. Library education in Papua New Guinea. Libri 38(1) 1988 51-70.

145. Evans, John. Papua New Guinea: short courses in librarianship. Int. Lib. Rev. 20(4) 1988 435-449.

146. Evans, John. Set for change: library education in Papua New Guinea. Educ. Lib. Aust. 5(2) 1988 71-76. 


\section{Poland}

147. DembowsKa, Maria. O statusie akademickim informacji naukowej. Akt. Prob. Inf. Dok. 33(1) 1988 10-13.

148. MichALSKI, Lech. Bibliotekarz-zawód czy zajęcie? Bibliotekarz 55(1-2) 1988 21-23.

149. Sleszenko, Jerzy and William, Norbert. Specializacja zawodowa pracownikov informacji naukowej i technicznez. Akt. Pro. Inf. Dok. 33(2) 1988 3-7.

150. WALCZAK, Marian. Doskonalenie zawodowe bibliotekarzy: bariery i perspektywy. Poradnik bibliotekarza 1988 (6) 8-12.

\section{Portugal}

151. Correia, Ana Maria Ramalho. Training information intermediaries in Portugal. Outlook on Research Libraries 10(9) 1988 4-9.

\section{South Africa, Republic of}

152. Swanepoel, A.J. Die getal studente Biblioteek- en Inligtingkunde departmente in Suid-Africa: 1984 tot 1987. S. Afr. J. Lib. \& Inf. Sci 56(1) 1988 11-17.

153. VISSER, M.S.P. Tendense in die Suid-Afrikaanse Biblioteek- en Inligtingkunde onderrigsituasie op Mesovlak. S. Afr. J. Lib. \& Inf. Sci. 56(1) 1988 27-37.

154. WALKER, Claire M. Out of Africa: pointers to possible developments in South African library education. Wits J. Lib. \& Inf. Sci. No. 51988 133-140.

\section{South America}

155. Robayo, Moisés Pedraza. Necesidad de principios orientadores de la formación de las professionales en información y documentación en América Latina. Revista AIBDA 9(1) 1988 29-41.

156. Villanueva, Carmen. Algunas consideraciones sobre la formación de los futuros professionales de la información en nuestro contexto. Revista AIBDA 9(1) 1988 71-28.

\section{Spain}

157. Massissimo, Angels and Mayol, Maria Carme. The educational framework for information professionals in Spain: a proposal and some suggestions. Education for Information 6(4) 1988 375-392. 


\section{United Kingdom}

158. Bowden, Russell. Transbinary Report: follow up. Lib. Ass. Rec. 90(3) 1988 147.

159. Education. In Library Association Annual Report and Accounts 1987. London: Library Association, 1988. pp. vi-vii. Also available as insert in Lib. Ass. Rec. 90(6) 1988.

\section{United States of America}

160. Doyle-Wilch, Barbara. Library education: a state perspective. Colorado Libraries 14(3) 1988 21-22.

161. Moll, Joy K. and Flood, Barbara J. Information science and information related educational programs: their diversity and accreditation. J. Amer. Soc. Inf. Sci. 39(5) 1988 318-322.

162. RobBINs, Jane. Education for librarianship: an essay. Illinois Libraries 70(8) $1988554-557$.

163. SinEATH, Timothy W. Library and information science education statistical report 1988. State College, PA: Association for Library \& Information Science Education, 1988.

164. VAN ORDEN, Phyllis. Library education. In ALA Yearbook of library and information services. Vol. 13. Chicago: American Library Association, 1988. ISBN 0 83890489 0. pp. 123-128.

165. WhITE, Herbert S. Basic competencies and the pursuit of equal opportunity, Part 1. Library Journal 113(12) 1988 56-57.

166. White, Herbert S. Basic competencies and the pursuit of equal opportunity, Part 2. Library Journal 113(15) 1988 62-63.

USSR

167. ANDREYeVA, I.M., SlyadNEVA, N.A. and Trapeznikova, L.V. On what should the training of highly qualified specialists be based? [In Russian]. Sov. Bib. 1988 (3) $26-31$.

168. ChernyaK, A. Ya. Higher library education at the threshold of a new stage. [In Russian]. Nauch. Tek. Bib. SSSR 1988 (7) 9-16.

169. Dzharylgasova, S.K. and Ratmanova, S.B. Once again on the necessity of library education reorganization. [In Russian]. Nauch. Tek. Bib. SSSR 1988 (12) $16-19$.

170. Elepov, B.S. and Zhdanova, T.A. On the necessity of reorganizing library education. Nauch. Tek. Bib. SSSR 1988 (4) 3-7. 
171. KICHIGINA, V. Who is taught in the vocational school and how? [In Russian]. Bibliotekar 1988 (1) 22-23.

172. KLyUyev, V.K. To learn to teach. [In Russian]. Sov. Bib. 1988 (3) 37-39.

173. MEJZHIS, I.A. Library profession-a librarian bibliographer. [In Russian]. Nauch. Tek. Bib. SSSR 1988 (9) 34-37.

174. OzARChuK, L.V. A new approach is needed. [In Russian]. Sov. Bib. 1988 (3) $36-37$.

175. Sinkiavicus, K.A. A new stage in the improvement of professional skills of librarians. [In Russian]. Sov. Bib. 1988 (6) 33-41.

176. Tereshin, V.I. The general scientific education of librarians in higher educational institutions. [In Russian]. Sov. Bib. 1988 (6) 41-48.

177. VASILCHENKo, N.P. Specification of positions based on principle. [In Russian]. Sov. Bib. 1988 (3) 32-35.

178. ZAZERSKY, E.Y. and Sokolov, A.B. The library profession today and tomorrow (research programme). [In Russian]. Sov. Bib. 1988 (2) 18-30.

\section{COMPARATIVE STUDIES}

179. CARPENTER, Ray L. Librarianship, education and service. Int. Lib. Rev. 20(2) 1988 127-134.

180. MCLEAN, Martin. Comparative perspectives on education and training: Britain and some other OECD countries. Assignation 6(1) 1988 3-5.

\section{LIBRARY AND INFORMATION SCIENCE SCHOOLS AND DEPARTMENTS}

\section{General}

181. Foster, William. OPAC design: a library school perspective. In Lorcan Dempsey, ed. Influencing the system designer: online public access to library files: third national conference. Oxford: Elsevier, 1988. ISBN 094639531 4. pp. 99-103.

182. LESTER, J. Roles of schools of library and information science. In Leadership for research libraries: a festschrift for Robert M. Hayes. Metuchen, NJ: Scarecrow, 1988. ISBN 081082129 X. pp. 126-148.

183. PARIS, Marion. Library school closings: four case studies. Metuchen, NJ: Scarecrow, 1988. ISBN 0810821303.

184. PARIs, Marion. Thoughts on the case study. J. Educ. Lib. \& Inf. Sci. 29(2) 1988 137-139. 


\section{Accreditation}

185. TotTen, Herman L. Accreditation. In ALA Yearbook of library and information services. Vol. 13. Chicago: American Library Association, 1988. ISBN 08389 0489 0. pp. $18-21$.

\section{Curriculum development}

186. BoRISOV, B.V. and TUTUNNIK, V.M. How to enhance technological training of library university graduates. [In Russian]. Sov. Bib. 1988 (4) 26-31.

187. Boumarafi, Behdija. Curriculum development. Libri 38(4) 1988 321-329.

188. DosA, Marta L. A könyvtarosok és információs szakemberek felkészítécserol egy amerikai megközelítésben. Tud. Mas. Taj. 35(4) 1988 160-169.

189. GaSh, Sarah and Reardon, Denis F. Personal transferable skills for the modern information professional: a discussion paper. J. Inf. Sci. 14(5) 1988 285-292.

190. LANEY, Elizabeth J. Library school curriculum: library publishing. Library Trends 36(4) 1988 709-723.

191. Large, J.A. A modular curriculum in information studies. Inf. Rep. \& Bib. 17(2) $19882-26$.

192. Mandillo, Anna Maria. Il gruppo nazionale sulla professione dell' AIB. AIB Boll. Inf. 28(1-2) 1988 37-39.

193. Morris, Anne and O'NeILL, Margaret. Information professionals-roles in the design and development of expert systems? Inf. Proc. \& Man. 24(2) 1988 173-181.

194. NASSIMBENI, Mary. The imperative for change: curriculum revision in South Africa. Education for Information 6(2) 1988 153-185.

195. RAJU, A.A.N. Need for modernisation and restructuring of LIS courses in India. In C.P. Vashishth, ed. Modernisation in libraries. Seminar Papers, 33rd All India Library Conference, 1987. Delhi: Indian Library Association, 1988. ISBN 81 8521618 5. pp. $165-170$.

196. Wood, Frances and Ellis, David. Employment patterns and curriculum development. Inf. \& Lib. Man, 7(5) 1988120.

\section{Courses /study-professional}

First qualification

197. BigGS, Mary and BooksteIn, Abraham. What constitutes a high-quality MLS program: Forty five faculty members' views. J. Educ. Lib. \& Inf. Sci. 29(1) 1988 $28-46$. 
198. BLACKIE, Edna. On designing an honours degree in Information and Library Studies. Training and Education 5(3) 1988 57-63.

199. Certificate of advanced study program in library and information science. Library Times International 4(4) 1988 56, 58.

200. Condron, Barbara J. and Godden, Irene. Graduate library education in Colorado. Colorado Libraries 14(3) 1988 10-12.

201. Course development. Ealing briefing Nov. 1988 [3-4].

202. D. LIS news. Ghaqda Bibliotekarji No. 601988 4-6.

203. Ellis, David. The teaching of information resource management at the University of Sheffield. Records Management Bulletin No. 28198812.

204. KHoo, Siew Mun. The MLIS programme at the Institute for Advanced Studies, University of Malaya. Education for Information 6(4) 1988 393-401.

205. McGarry, Kevin. The Applied Social Science Modular Scheme: BSc in Information and Communication Studies: 1988. Education for Information 6(4) 1988 425-430.

206. McKeE, Bob. A források; fajtáik és fejldesuk. Tud. Mus. Taj. 35(4) 1988 141-144.

207. MineUR, B.W. Law and librarianship. Law Librarian 19(1) 1988 1-4.

208. ONADIRAN, G.T. Reactions of past students to the Bachelor of Library Science degree of Ahmadu Bello University, Zaria, Nigeria. Education for Information 6(1) 1988 39-59.

209. PeTtus, Eloise S. Master of Library and Information Science program begins. Kekal Abadi 7(1) 1988 1-8.

210. Petrus, Eloise S. The MLIS at the IPT: a comparison with American Masters' programmes; with some recommendations for the future. Kekal Abadi 7(2) 1988 $1-3$.

211. Petrus, Eloise S. MLIS programme begins at University of Malaya. International Leads 2(2) 1988 1-2.

212. Robertson, S.E. and YATES-MerceR, P.A. Information technology, systems and management: education and training. Int. J. Inf. Man. 8(1) 1988 55-60.

213. SANDOw-QUIRK, Mary. Teaching information management: a new degree offered at the Queensland Institute of Technology. Educ. Lib. Aust. 5(2) 1988 107-109.

214. WaLters, Corky. Climbing toward an MLS. Colorado Libraries 14(3) 1988 $13-14$.

215. White, Herbert S. Generalization versus specialization in the MLS. Library Journal 113(3) 1988 148-149. 
Courses / study - paraprofessional

216. Bowman, Robert J. Library technicians under and over. Canadian Library Journal 45(4) 1988 229-233.

217. Bueno, Jo. Paralibrarian education: the information/library technician curriculum at Pikes Peak Community College. Colorado Libraries 14(3) 1988 17-18.

218. Hyland, Margaret. Automation and the training of library technicians in Australia. Australasian College Libraries 6(2-3) 1988 59-63.

219. Kerham, A.S. The education of library technicians in South Africa. S. Afr. J. Lib. \& Inf. Sci. 56(1) 1988 7-10.

220. Librarianship training: Technikon vs University. SAIBI Nuusbrief 8(11) 1988 5.

221. NAYLOR, P. et al. Education for library technicians in Australia. Educ. Lib. Aust. 5(2) 1988 77-82.

222. Sercombe, Linda. Working and studying as a library technician. Australasian College Libraries 6(1) 1988 19-23.

223. Stanke, Nicky. Training the nondegreed library worker: how it is and how it should be done. Public Libraries 27(2) 1988 79-81.

\section{Courses / study—non-professional}

224. Markham, Colin. A library assistant's story. Library \& Information Assistant Summer 1988 4-5.

225. MERRYWEATHER, Jill. Get in and win: studying for the City and Guilds Library and Information Assistant's Certificate. Library Work No. 1198818.

226. Orientierungshilfen zum lernzielorientierten Lehrplan "Bibliotheksfachkunde" an den Berufsschulen. Biblio 37(2) 1988 19-36.

227. Prüfungsausschüsse für den Ausbildungsberuf Assistent/in an Bibliotheken-Amtszeit 1988-1991. Biblio 37(2) 1988 37-41.

228. Verordnung über die Berufsausbildung zum Assistenten an Bibliotheken vom 20 Juni 1975 mit Ausdbildungsrahmensplan für die Berufsausbilding zum Assistenten an Bibliotheken. Biblio 37(2) 1988 41-48.

229. Zimbabwe-training in library work. COMLA newsletter No. 621988 6-7.

230. Zur Ausbildung von Assistenten/Assistentinnen an Bibliotheken in Nordrhein-Westfalen. Biblio 37(2) whole issue. 


\section{Modes of study}

\section{Distance education}

231. CLYDE, Laurel A. Potential external student's access to media, computing and library resources: a survey. Educ. Lib. Aust. 5(3) 1988 135-148.

232. CraIG, David. Higher Certificate in Library and Information Science: a distance learning course for senior library assistants. Learning Resources Journal 4(3) 1988 113-122.

233. JOEL, Alfred. Pioneering in library learning. Library \& Information Assistant Winter 1988 20-21.

234. LOCKE, Joanne and GALlER, Anne M. Breaking out with books. Canadian Library Journal 45(2) 1988 77-81.

235. MiNG, Marilyn. Training support staff for school libraries: an innovative distance education program. School Libraries in Canada 8(2) 1988 29-34.

236. Rural Library Training Project. APLA Bulletin 51(4) 19883.

237. SMITH, Jeremy. Distance learning with NALGO brings a library qualification within reach. Library \& Information Assistant Winter 1988 18-19.

238. SMITH, Jeremy. Qualifications by post: distance learning with NALGO brings a library qualification within reach. Library Work No. 219886.

239. VAN DER MERWE, M.S. Distance education in cataloguing and classification. Mousaion Ser. 3 6(1) 1988 45-55.

\section{Teaching methods}

240. CoRNeLIUS, Ian. ZePHYR: an in-house information retrieval system for library education. An Leabharlann 2nd Ser. 4(3) 1988 69-76.

241. CRAWford, Gregory A. Training student employees by videotape. Coll. \& Res. Lib. News 49(3) 1988 149-150, 152.

242. DAY, Joan M. CD-ROM-An online training tool? Education for Information 6(4) 1988 403-410.

243. DAY, Joan M. and O’Donovan, K. Online education and marketing: a joint approach. Education for Information 6(3) 1988 315-322.

244. Dou, Henri, Quoniam, Luc and Hassanaly, Parina. Teaching bibliometric analysis and MS/DOS commands. Education for Information 6(4) 1988 411-423.

245. ERzsÉBET, Tokaji Nagy and Minaty, Pálvölgyi. Introduction to the use of computers in library science education in Hungary. IATUL Quarterly 2(4) 1988 237-241. 
246. Gothberg, Helen M. and Aleamoni, Lawrence M. The comprehensive examination. J. Educ. Lib. \& Inf. Sci. 29(1) 1988 47-56.

247. Hannabus, Stuart. Training and learning styles. Inf. \& Lib. Man. 7(4) 1988 93-97.

248. HowDEN, Norman. Advanced preparation in microcomputer systems. J. Educ. Lib. \& Inf. Sci 29(1) 1988 15-27.

249. HowDEN, Norman and Boyce, B.R. The use of CAI in the education of online searchers. J. Educ. Lib. \& Inf. Sci. 28(3) 1988 201-206.

250. KARETZKY, Stephen. Videocassette kits for instruction in online searching. Coll. \& Res. Lib. News 49(6) 1988 360-364.

251. KIRKhaM, Sandi. Teaching humanities librarianship: the role of information technology. Lib. Ass. Rec. 90(2) 1988 98-99.

252. MARTIN, Gillian. Data display panel: the ELF DD-1000. Education for Information 6(2) 1988 211-212.

253. MASCIONI, Michael. Optical media in training. Optical Information Systems 8(4) 1988 184-189.

254. National Library offers database access to library schools. National Library News 20(9) 19886.

255. OUdEGROENIGER, Ben. ADLIB in die studierichting BDI: gebruik, toepassingen en ervaringen. Open 20(1) 1988 14-17.

256. Prevot, Martine and Waller, Suzanne. Systèmes modulaires de formation: application à l'information et à la documentation. Deuxième partie. Documentaliste 25(3) 1988 136-140.

257. REDDY, J. Yadagiri et al. Impact of new technology on manpower training for library and information activities. In C.P. Vashishth, ed., Modernisation in libraries. Seminar Papers, 33rd All India Library Conference, 1987. Delhi: Indian Library Association, 1988. ISBN 818521618 5. pp. 171-174.

258. ReVILL, D.H. An availability survey in cooperation with a School of Librarianship and Information Studies. Library Review 37(1) 1988 17-34.

259. Rowley, J.E. et al. The use of INFO, a database management system in teaching library and information studies at Manchester Polytechnic. Education for Information 6(1) 1988 71-82.

260. SINGH, S. et al. Use of audio-visual aids in LIS teaching in India. In C.P. Vashishth, ed. Modernisation in libraries. Seminar Papers, 33rd All India Library Conference, 1987. Delhi: Indian Library Association, 1988. ISBN 818521618 5. pp. 449-455. 
261. WADE, Stephen J. and WilletT, Peter. INSTRUCT: a teaching package for experimental methods in information retrieval. Part 3. Browsing, clustering and query expansion. Program 22(1) 1988 44-61.

\section{Specialised education}

Academic librarianship

262. Simonov, B.A. On the content of pedagogical training of personnel for special libraries in higher educational institutions. [In Russian]. Sov. Bib. 1988 (2) 73-75.

Art librarianship

263. Education Committee 1987-88. ARLIS News-sheet No. 7119887.

Audiovisual librarianship

264. Giraud, Odile. Les formations courtes en documentation audiovisuelle. Documentaliste 25(2) 1988 84-87.

\section{Bibliotherapy}

265. KoZAKIEWICZ, Wanda. Specjaliści biblioterapeuci. Poradnik Bibliotekarza 1988 (1-2) 22-23.

Business librarianship

266. Training for the business librarian. Business Library Management 1(5) 1988 $3-22$.

\section{Children's librarianship}

267. Association for Library Service to Children. Education Committee. Competencies for librarians serving children in public libraries-a draft report. ALSC Newsletter 9(2) 1988 3-4.

\section{Humanities librarianship}

268. BIERBAUM, Esther Green. Museum, arts and humanities librarians: careers, professional development and continuing education. J. Educ. Lib \& Inf. Sci. 29(2) 1988 127-134. 
Law librarianship

269. SeADER, Jane. Employment as a law librarian. New Jersey Libraries 21 (2) 1988 $5-7$.

270. SLINGer, Michael J. Career paths and education of current academic law library directors. Law Library Journal 80(2) 1988 217-239.

Local studies librarianship

271. PAUL, Derryan. Reference and information work in local history: training for librarians. Education for Information 6(3) 1988 323-338.

Map librarianship

272. GelFand, Julia. Becoming a map librarian: is graduate library education doing what it should? Inf. Bull. West. Ass. Map. Lib. 19(4) 1988 220-223.

273. Krogt, P.C. van der. De opleiding Kaart- en Atlasbeheer Go-H. Open 20(1) 1988 6-9.

274. Seavey, Charles A. and Clark, Suzanne M. Library education to work with maps. J. Educ. Lib. \& Inf. Sci. 29(2) 1988 121-126.

Medical and health sciences librarianship

275. KUMAR, R.P. Educational needs and requirements of health sciences librarians in the Third World. International Library Movement 10(2) 1988 85-92.

276. Morgan, Peter B. A workshop for medical librarians in Pakistan. Health Libraries Review 5(1) 1988 7-10.

277. PACHMAN, Frederic C. Employment as a health science librarian. New Jersey Libraries 21(2) 1988 3-5.

Music librarianship

278. Gebolys, Zdzislaw. Kształcenie bibliotekarzy muzycznych w Republice Federalnej Niemiec. Bibliotekarz 55(10-11) 1988 35-38.

279. Sommer, Susan T. Teaching collection development in context. Fontes Artis Musicae 35(3) 1988 195-197.

Public librarianship

280. Jolivet, Linda C. Preparation of librarians to serve a multicultural world. WLW Journal 12(2) 1988 3-6. 
281. LoCKETT, Mary. Preparing librarians to serve ethnic communities. J. Educ. Lib. \& Inf. Sci. 29(2) 1988 141-142.

282. Ming, Marilyn. Training staff for Canada's rural school and public libraries. Libraries Alone 1(1) 1988 21-27.

283. Usherwood, Bob and Vessey, Shirley. Public library education-the decline of a discipline. Public Library Journal 3(2) 1988 25-29.

\section{Rare book librarianship}

284. Tilley, Christine M. Trends in education for rare book and special collections librarianship. Educ. Lib. Aust. 5(2) 1988 99-106.

School librarianship

285. Evans, John. The state of school libraries and training for school librarians in Papua New Guinea. Education Libraries Bulletin 31(3) 1988 33-42.

286. Hallein, Joe. Education for teacher librarianship in Australia. Educ. Lib. Aust. 5(2) 1988 83-86.

287. HEMPSTEAD, John. Educational requirements update for school media library personnel. Colorado Libraries 14(3) 1988 23-24.

288. HUG, William E. School library media education and professional development. Sch. Lib. Med. Q. 16(2) 1988 115-118.

289. Miller, Marilyn L. ALA/NCATE: an education for school librarianship. Catholic Library World 60(2) 1988 76-80.

290. Szocki, J. Uwagi o kształceniu, dokształaniu i doskonaleniu nauczcieli-bibliotekarzy z bibliotek szkolnych. Bibliotekarz 55(4-5) 1988 10-15.

291. Teacher-librarian course has budget axed. Library Life No. 11819881.

Special librarianship

292. Crasta, Madel. Formazione e identitá professionale dei bibliotecari dei Ministeri. AIB Boll. Inf. 28(1-2) 1988 91-92.

293. Deogan, M.S. Educating special librarians for the 21st century. Lucknow Librarian 20 (1) 1988 18-22.

294. Walter, Raimund-Ekkehard. Die Ausbildung des mittleren Bibliotheksdienstes an der Staatsbibliothek. Mitt. SBPK 20(1) 1988 14-25.

295. Williamson, Joan. One person libraries and information units: their education and training needs. Bradford: MCB University Press, 1988. ISBN 0861763548. Also published as Library Management 9(5) 1988. 
Theological librarianship

296. Gibson, Ruth. So you want to work in a theological library. Lib. Chr. Fellow. News No. 391988 24-29.

\section{Teaching individual subjects}

Acquisitions / Collection development

297. Rahman, Afifa. Acquisitions and collection development education in Bangladesh. Lib. Acq. Prac. \& Theory 12 (1) 1988 43-51.

\section{Bibliography}

298. ShAPIRO, E.L. Flaws in training special bibliographers; what knowledge they should possess. Nauch. Tek. Bib. SSSR 1988 (8) 12-14.

\section{Business information}

299. KAYE, David. Teaching business information: the Manchester experience. Business Information Review 4(4) 1988 28-36.

300. RoberTs, N., Wilson, T.D. and Ellis, D. Business information sources: a consideration of requirements. Education for Information 6(1) 1988 27-37.

Cataloguing and indexing

301. BiERMAN, Esther Green. Teaching the cataloging of three-dimensional objects. J. Educ. Lib. \& Inf. Sci. 29(1) 1988 3-4.

302. Goodell, John. The future of cataloguing as a core subject. Educ. Lib. Aust. 5(2) 1988 93-97.

303. SeLlBERG, Roxanne. The teaching of cataloguing in U.S. library schools. Lib. Res. \& Tech. Serv. 32(1) 1988 30-42.

304. Weinberg, Bella Hase. A graduate level course on Hebraica and Judaica cataloguing. Judaica Librarianship. 4(1) 1988 85-88.

Computing and information technology

305. DYER, Hilary. Teaching library automation. Aslib Information 16(9) 1988230.

306. MonjaU, Dieter. Programmiersprachliche Grundlagenausbildung in der Informatik. Rechen. Daten. 25 (3) 1988 17-18, 23. 
307. PrƯrer, Christina. Zur Problematik der Prägung einer formallogischen Denkweise bei Bibliotheks- und Informationskräften hinsichtlich des Einsatzes moderner Informations- und Kommunikationstechnologien. Informatik 1988 (6) 236-237.

308. Sidhu, M.S. and Navalani, K. Manpower education and training in India in computer application to library and information activities: a survey. In C.P. Vashishth, ed. Modernisation in Libraries. Seminar Papers, 33rd All India Library Conference 1987. Delhi: Indian Library Association, 1988. ISBN 818521618 5. pp. $175-181$.

309. SingH, Sewa. Advanced level institute on computer application in libraries. Herald of Library Science 27(1-2) 1988 89-91.

310. Surya RaO, G and AnURAdha, M. Manpower development for computerised library and information services in university libraries in India. In C.P. Vashishth, ed. Modernisation in Libraries. Seminar Papers, 33rd All India Library Conference, 1987. Delhi: Indian Library Association, 1988. ISBN 818521618 5. pp. 182-188.

\section{Conservation and preservation}

311. Dartnall, Jean. Library conservation in the tropics. Educ. Lib. Aust. 5(1) 1988 10-17.

312. Education for preservation. Footnotes 18(1) 1988 7, 9.

313. Feather, John and LUSHER, Anne. The teaching of conservation in LIS schools in Great Britain. London: British Library Research and Development Department, 1988 (British Library Research Paper, 49) ISBN 0712331751.

314. Harvey, Ross. Nothing left to access? The problems of deteriorating newspapers. Educ. Lib. Aust. 5(1) 1988 18-26.

315. IBRAHIM, M.Z. The teaching of preservation and conservation at Bayero University, Kano, Nigeria. Restaurator 9(1) 1988 51-60.

316. Loughridge, Brendan. Conservation, culture and curriculum. In A.H. Helal \& J.W. Weiss, eds. International Library Cooperation, Procs. 10th Anniversary Essen Symposium, 1987. Essen: Universitätsbibliothek Essen, 1988. ISBN 3922602118. pp. 18-38.

317. TURNER, John. Teaching conservation. Education for Information 6(2) 1988 $145-151$.

\section{Information retrieval}

318. HEPWORTH, John B. Database teaching in the information storage and retrieval syllabus. Education for Information 6(1) 1988 3-25.

319. Wood, F.E. Guidelines for teachers of online information retrieval. Paris: General Information Programme and Unisist, Unesco, 1988. (PGI-88/WS/7). 
Intellectual property

320. Harding, Christopher, Ireland, Richard and Williams, John. Legal education: outreach to the professions and the community. Law Librarian 19(1) 1988 $27-31$.

\section{Management}

321. Ritchie, Sheila. Ferret breeding for librarians: management education and training for librarians. Inf. \& Lib. Man. 7(4) 1988 84-87.

322. SzePESVÁRY, Tamás. A könyvtárvezetés oktatásának kérdéséhez. Tud. Mus. Taj. 35(4) 1988 156-159.

323. UsERHWOOD, Bob. Megjegyzések a vezetestudomany helyéröl a könyvtárosképzésben. Tud. Mus. Taj. 35(4) 1988 152-155.

324. VINCENT, Ida C. Reflections on the teaching and learning of management in initial professional education for librarianship programs. J. Educ. Lib. \& Inf. Sci. 28(3) 1988 177-187.

325. WebB, Gisela, Personnel officers: judging their qualifications. Wilson Library Bulletin 62(6) 1988 44-46.

Marketing

326. SaVARD, Réjean. Principes directeurs pour l'enseignement du marketing dans la formation des bibliothécaires, documentalistes et archivistes. Paris: Unesco, 1988 (PGI-88/WS/1).

Reference and information service

327. Santos Campello, Bernadete and Albino Andrade, Maria Eugenia. Fontes de Informaçao para bibliotecas publicás e communitárias brasilieras: proposta para seu estudo nos cursos de Biblioteconomia. Rev. Esc. Bib. UFMG. 17(2) 1988 173-185.

328. Usherwood, Bob. A források; tajtáik és fejlödésük. Tud. Mus. Taj. 35(4) 1988 $141-144$.

Systems analysis

329. Boyce, Bert R. and Heim, Kathleen M. The education of library systems analysts for the nineties. J. Lib. Admin. 9(4) 1988 69-76.

User education

330. FrICK, Elizabeth. British graduate education. APLA Bulletin 51(4) 1988 7-8. 


\section{Practical work experience}

331. Ausbildung fur die praktische Ausbildung und den praxisbegleitenden Unterricht in den Ausbildungsbibliotheken. Biblio 37(2) 1988 2-18.

332. Strubbe, Lisa Aren and Schwartz, Diane G. A two-year MLS internship program. Coll. \& Res. Lib. News 49(8) 1988 504-508.

333. StuART, Elizabeth A. A question of culture: the usefulness of study tours abroad. J. Soc. Arch. 9(2) 1988 84-87.

334. Thomas, W.M. The practical experience component in the education programme of students in Library and Information Science at Unisa. Mousaion Ser. 3 6(1) 1988 32-44.

335. YeRBURY, Hilary. Introducing students to the world of information work. Educ. Lib. Aust. 5(3) 1988 151-153.

\section{Teaching staff / Faculty}

336. Boyce, Bert R. and Youngsuck, Cho. Tracking School of Library and Information Science faculty productivity. J. Educ. Lib. \& Inf. Sci. 29(1) 1988 63-65.

337. CARrigan, Dennis. The Dean as manager: strategic planning for the library school. Wilson Library Bulletin 62 (10) 1988 82-84.

338. GRACY II, David B. The role of faculty in professional associations: the Society of American Archivists. J. Educ. Lib. \& Inf. Sci. 29(2) 1988 108-112.

339. HeIM, Kathleen M. Faculty impact on information policy and recruitment of excellent students: reflections on ALISE presidential year, 1987. J. Educ. Lib. \& Inf. Sci. 28(3) 1988 207-210.

340. Lenox, Mary F. and Ezell, Charlaine. I for an I: faculty development through library experience. J. Educ. Lib. \& Inf. Sci. 28(3) 1988 228-231.

341. LYNCH, Mary Jo. Faculty involvement in ALA. J. Educ. Lib. \& Inf. Sci. 29(2) 1988 99-107.

342. Martin, W.J. A day in the life of ... Aslib Information 16(3) 1988614.

343. MorAN, Barbara B. Can (greying) faculty shape policy: a report on the library educators' conference in San Antonio. American Libraries 19(3) 1988 182-183.

344. Nicholson, Faye. Professional interaction between library educators. Educ. Lib. Aust. 5(2) 1988 121-123.

345. Seventeen states and a province honor library educators. American Libraries 19(4) 1988318. 
346. STUEART, Robert D. Human relations in library education: relationships among colleagues. In Procs. IFLA General Conference, 54th, Sydney, 1988. (Paper 52TRAIN-2-E).

347. Sullivan, Peggy. Faculty participation in university policy formation: the pleasures and the perils. J. Educ. Lib. \& Inf. Sci. 29(2) 1988 113-120.

348. Venkatappaiah, V. Principal Hogg receives Kaula award for 1986. Herald of Library Science 27(3-4) 1988220.

349. William Foster. BLCMP News No. 519884.

\section{Students}

350. Bartczak, Jan. Absolwenci Panstwowego Studium Bibliotekarskiego w Jarocinie sami o sobie. Bibliotekarz 55(3) 1988 3-6.

351. British Library Association issues statements on recruitment of black librarians and on equal opportunities in employment. J. Mul. Lib. 2(2) 1988 42, 44.

352. BudD, John M. The best and the brightest. Lib. Admin. \& Man. 2(2) 1988 103-104.

353. Conway, Patrick. The ones that we want. Public Library Journal 3(2) 1988 $30-32$.

354. ElKIN, Judith. Recruitment of people from minority ethnic groups into the library information workforce. [Report of a seminar at Birmingham Polytechnic Department of Librarianship and Information Studies 18/1/88]. J. Mul. Lib. 2(2) 1988 61-68.

355. Moen, William E. and HeIM, Kathleen M. The class of 1988: librarians for the new millenium. American Libraries 19(10) 1988 858-860, 885.

356. Pearson, Richard C. and WebB, T.D. The new librarians: how prepared are they? Library Journal 113(14) 1988 132-134.

357. SABLE, Martin H. Educational-vocational guidance. Int. Lib. Rev. 20 (3) 1988 361-366.

358. Scarborough, Katie and Nyhan, Constance W. Meeting the need for librarians: the California Library School Recruitment Project. Library Journal 113(17) 1988 44-49.

359. Tilley, Christine M. Female librarianship in Australia. Int. Lib. Rev. 20 (4) 1988 425-433.

360. VAN House, Nancy A. MLS students choice of a library career. Lib. \& Inf. Sci. Res. 10(2) 1988 157-176. 
Library and information schools and departments-individual schools

361. ABIDI, Syed Ameer Haider. East African School of Librarianship, Makerere University. Africana Libraries Newsletter No. 541988 2-3.

362. Abschlussarbeiten des postgradualen Fernstudiums am Institut für Bibliothekswissenschaft und wissenschaftliche Information der Humboldt-Universität zu Berlin 1987. Informatik 1988 (5) 198-200.

363. ANDERSON, James D. et al. Information science at Rutgers: establishing new interdisciplinary connections. J. Amer. Soc. Inf. Sci. 39(5) 1988 327-330.

364. DAwson, Alma. The Library and Information Science Library of Louisiana State University: a resource for professional librarians. LLA Bulletin 50(3) 1988 121-124.

365. FARrow, Catherine and VAN DER StARre, Jan. Uit de praktijk van... Informatie-technologie aan de FMA. Open 20(2) 1988 44-47.

366. KAJBERG, Leif. Research at the Royal School of Librarianship, Copenhagen. Lib. \& Inf. Res. News 11(41) 1988 12-14.

367. KAJBERg, Leif. The Royal School of Librarianship in Denmark. J. Educ. Lib. \& Inf. Sci. 29(2) 1988 145-149.

368. LAJEunESSE, Marcel and SAVARD, Réjean. The University of Montreal and French language library education. J. Educ. Lib. \& Inf. Sci. 29(1) 1988 69-74.

369. Louw, Anna. Review of the objectives, methods, accountability and future planning of the Department of Library and Information Science of the University of South Africa (UNISA). Mousaion Ser. 3 6(1) 1988 21-31.

370. Musisi, J.S. A Faculty of Information Sciences at Moi University Kenya. COMLA Newsletter No. 611988 8-10.

371. Setrel, Barbara and Marchand, Donald A. Syracuse University School of Information Studies: a tradition of innovation. J. Amer. Soc. Inf. Sci. 39(5) 1988 $331-333$.

372. Walczak, Marian. Państwowy Ośrodek Kształcenia Bibliotekarzy w Jarocinie po czterdziestu latach słuzby dla kształcenia i doskonalenia zawodowego bibliotekarzy. Bibliotekarz 55(9) 1988 3-10.

373. Woodward, Diana. Drexel University College of Information Studies: evolving programs, new connexions. J. Amer. Soc. Inf. Sci. 39(5) 1988 334-336.

\section{PROFESSIONAL QUALIFICATIONS}

374. Changes to Library Association of Australia's conditions for professional membership. Aust. Soc. Arch. Bull. No. 771988 5-7. 
375. Harrison, Colin T. Writing a Professional Development Report. Lib. Ass. Rec. 90(3) 1988 158-160, 163.

376. Hewletr, John. Pre-registration training in health-care libraries. II. Progress assessment checklist. Health Libraries Review 5(4) 1988 237-245.

377. HewletT, John. Training for Library Association chartering in health-care libraries. Health Libraries Review 5(3) 1988 181-188.

378. Library Association of Australia to change conditions for professional membership. Educ. Lib. Aust. 5(1) 1988 39-40.

379. Perritt, Patsy H. School library media certificate requirements: 1988 update - Part I. Certification requirements. School Library Journal 34(10) 1988 31-39.

380. Perritr, Patsy H. School library media certification requirements: 1988 update - Part II. Knowledge/subject areas/competencies/skills. School Library Journal 34(11) 1988 32-40.

381. Poole, Andrew. Which route to follow? Library Work No. 21988 20-21.

382. Register of Qualified Librarians. Ghaqda Bibliotekarji No. 601988 1-3.

383. Shimmon, Ross. Paraprofessionals and the Library Association. Lib. \& Inf. Ass. Winter 1988 10-11.

384. WALUZYNIEC, Hanna. MLA certification. Bibliotheca Medica Canadiana 9(3) 1988 137-138.

385. Woolley, Marcus. The one-person library: professional development and professional management. Bradford: MCB University Press, 1988. ISBN 086176 339 4. Also published as Library Management 9(1) 1988.

\section{CAREER DEVELOPMENT}

386. Business librarians who did something else. Business Library Management 1(8) 1988 3-18.

387. Career prospects for library and information assistants. Lib. \& Inf. Ass. Summer 1988 10-11.

388. CARGILL, Jennifer. Career development: it's your option. Coll. \& Res. Lib. News 49(8) 1988 513-517.

389. CleGG, Helen. Attitudes to continuing professional development: a survey of members of the Institute of Information Scientists. MSc Thesis, Loughborough University of Technology, 1988.

390. FogGin, Carol M. Reentry: a viable option for professionals. Lib. Admin. \& Man. 2(3) 1988 137-140. 
391. Greiner, Joy M. A comparative study of the management styles and career progression patterns of recently appointed male and female public library administrators (1983-1987). In G.B. McCabe and B. Kriessman, eds. Advances in Library Administration and Organization Vol. 7. Greenwich, CT; London. JAI Press 1988. ISBN 089232817 7. pp. 1-27.

392. Hulme, Amanda J. and Wilson, T.D. Professional education and subsequent careers in library/information work: a follow-up study of former students on the MA/MSc Information Studies (Social Sciences) course at the University of Sheffield. J. Inf. Sci. 14(2) 1988 109-117.

393. Kong, Leslie M. and Goodfellow, R.A.H. Charting a career path in the information professions. Coll. \& Res. Lib. 49(3) 1988 207-216.

394. LaCey BRyant, Sue. Women not in libraries. New Library World 89(1060) 1988 187-188.

395. Loughridge, Brendan and Sutton, Jane. The careers of MA graduates: training, education and practice. Journal of Librarianship 20 (4) 1988 255-269.

396. Martin, S.C. Keynote address for the First Annual Regional Conference of Library Assistants. J. Educ. Lib. \& Inf. Sci. 28(4) 1988 259-261.

397. Merz, Mildred. Career plateauing. National Librarian 13(2) 1988 2-4.

398. MoRris, Beryl. Back to business. Lib. Ass. Rec. 90(10) 1988576.

399. Pateman, John. Two tribes. New Library World 89(1057) 1988126.

400. Ritchie, Sheila. Training and management development in librarianship. London: British Library Research and Development Department, 1988 (Library and information research report, 34). ISBN 0712330496.

401. Rux, Paul. Teach or manage? Career models for librarians. Library Journal 113(19) 198832.

402. Segal, Barbara. Aurora Public Library career development plan. Colorado Libraries 14(3) 1988 9-10.

403. SMith, Chris M. Non-professional careers in the East Sussex County Library service. Lib. \& Inf. Ass. Summer 1988 14-17.

404. Steele, Donald. Career prospects-do they exist? Lib. \& Inf. Ass. Winter 1988 4-5.

405. TAGUE, Jean and HARRIS, Roma. Evolutionaries and revolutionaries: careers of Canadian library directors. Canadian Library Journal 45(4) 1988 236-243.

406. WhITE, Brenda. Apologia pro vita sua: career profiles of senior library/ information people. London: British Library, 1988 (British Library research paper, 46). ISBN 0712331727. 
407. Williamson, Linda Eileen. Going international: librarian's preparation guide for a work experience/job exchange abroad. Chicago: American Library Association, 1988. ISBN 0838912683.

408. WISE, M.C.G. LIBEX: the Bureau for International Staff Exchange initiated by the ICLG: report for 1987. Foc. Int. \& Comp. Lib. 19(1)(67) 19882.

\section{CONTINUING EDUCATION}

409. Asp, William G. Continuing Library Education Network and Exchange Round Table. In: ALA Yearbook of library and information services. Vol. 13. Chicago: American Library Association, 1988. ISBN 083890489 0. pp. 118-119.

410. Birmingham, Mary Treacy and Mahmood, Suzanne H. If you believe in the power of information, you must exercise the power it gives. Library Personnel News 2(3) 1988 41-42.

411. Сновот, Mary C. Improving the quality of continuing education. In Procs. IFLA General Conference, 54th, Sydney, 1988 (Paper 63-RTCPE-1-E).

412. Continuing education: what's the point. One-person Library 4(12) 1988 6-7.

413. Continuing professional education. IFLA Journal 14(1) 1988 77-78.

414. Feather, John and Smith, Inese A. Post-qualification training. Int. Lib. Rev. 20(4) 1988 459-468.

415. Hartman, Susan E. The continuing saga of library life in Littleville. Colorado Libraries 14(3) 1988 25-26.

416. IFLA. Continuing Professional Education Round Table. Annual report 1986/87. In IFLA Annual 1987. Procs. 53rd Council \& General Meeting, Brighton 1987. München; New York; London. Saur: 1988. ISBN 359820668 2. pp. 189-192.

417. JeSPERSEN, Sherry. Professional Development and Information Group report 1987. Aslib Information 16(6) 19888.

418. KAJBERG, Leif. Continuing education in Denmark's Royal School of Librarianship. Educ. Lib. Aust. 5(3) 1988 149-150.

419. KNEPEL, Nancy. Library continuing education: a regional library service system's perspective. Colorado Libraries 14 (3) 1988 18-20.

420. McCrossan, John A. Public library administrators' opinions of continuing education activities. Public Libraries 27(1) 1988 47-49.

421. ManCall, Jacqueline C. and Bertland, Linda H. Step One reported: analysis of AASL's First Needs Assessment for Continuing Education. Sch. Lib. Med. Q. 16(2) 1988 88-98. 
422. Phillips, John C., Freimer, Gloria and Mclean, Dulci Didio. A new direction for continuing education at Carlson Library. J. Acad. Lib. 13(6) 1988 340-344.

423. Phillips, Sue. An Australian approach to continuing professional education. In Procs. IFLA General Conference, 54th, Sydney, 1988 (Paper 82-RTCPE-2-E).

424. Powell, Ronald R. Sources of professional knowledge for academic libraries. Coll. \& Res. Lib. 49(4) 1988 332-340.

425. Shaughnessy, Thomas W. Staff development in libraries: why it frequently doesn't take. J. Lib. Admin. 9(2) 1988 5-12.

426. Shimmon, Ross. Staff development: initial professional and continuing education in a changing environment. In J.G. Brewer, ed. Educational developments: the challenge to library and learning resource services. Papers of the Joint Annual Study Conference of COFHE and the Education Librarians Group, 1987. Cambridge: L.A. COFHE, 1988. ISBN 186997703 3. pp. 36-41.

427. SLATER, Margaret. Internal training and external short courses: a study of informal continuing education in the special sector of the library/information field. London: British Library, 1988 (British Library research paper, 52).

428. Sмiтh, Jane Bandy, ed. Continuing to learn. [7 articles on continuing education and staff development. Sch. Lib. Med. Q. 16(2) 1988 83-121.

429. SoRENSEN, Richard J. Continuing education in the American Library Association. Sch. Lib. Med. Q. 16(2) 1988 119-121.

430. StARKe, Nancy A. Library continuing education needs in Kansas: the rural perspective. Rural Libraries 8(1) 1988 39-70.

431. STONE, Elizabeth W. Personnel and employment: continuing education and staff development. In ALA Yearbook of library and information services. Vol. 13. Chicago: American Library Association, 1988. ISBN 0838904890 pp. 242-245.

432. WATKIns, J. Foster and CRAFT, Anne Hale. Library media specialists in a staff development role. Sch. Lib. Med. Q. 16(2) 1988 110-114.

433. Weingand, Darlene E. Continuing education. [Column]. J. Educ. Lib. \& Inf. Sci. 29(1) 1988 66-68.

434. Weingand, Darlene E. Continuing education in information technology. Inspel 22(3) 1988 226-229.

435. Wilkinson, John and MURRAY, Carolyn. Continuing education for librarianship: who benefits and why? Canadian Library Journal 45(1) 1988 42-46. 


\section{TRAINING}

\section{General}

436. BLANKSBY, Margaret. Staff training: a librarian's handbook. Newcastle under Lyme: Association of Assistant Librarians, 1988. ISBN 0900092688.

437. CARVER, Deborah A. Transfer of training: a bibliographic essay. Lib. Admin. \& Man. 2(3) 1988 151-153.

438. Geretto, Paolo. Il settore privativo: interventi formativi e diaggiornamento. AIB Boll. Inf. 28(1-2) 1988 117-120.

439. GETZ, Malcolm. Responding to the labor market: matching salaries and paying for training. Bottom Line 2(2) 1988 34-35.

440. Hellen, Bob. Survey of training materials. London: Library Association, 1988.

441. Interview with Gwenda Sippings, Aslib's Training Programme Organiser. Aslib Information 16(3) 198865.

442. LeITCH, Elizabeth. Professional training programme. Scot. Acad. Lib. News. 1(2) 1988 9-10.

443. Majima, Hajime. Training courses for information users at the British Library. [In Japanese]. Joho-no Kagaku To Gijutsu 38(4) 1988 173-176.

444. Welsh Libraries' Training Group. Train. \& Educ. Group Mem. News. 5(1) $1987 / 88$ B.

\section{Specialised}

445. AARON, Shirley L. The role of professional development activities in promoting improved instructional services in the library media program. Sch. Lib. Med. Q. 16(2) $198884-87$.

446. AL-SABAGH, Imad A.W. Staff development programmes in university libraries. [In Arabic]. Rissalat al-Maktaba 23(2) 1988.

447. BeDnarek, Irmina. Działalność szkoleniowa ośrodków resortowych. Akt. Prob. Inf. Dok. 33(3) 1988 19-23.

448. Biblioteksutvikling 1988: Program for ledelses- og organisasjonsutvikling. Synopsis 19(3) 1988 143-146.

449. BовоK-BÉlanYe, Béata. Az állományalakítas oktatási kérdési. Tud. Mus. Taj. 35(4) 1988 145-148.

450. Borssk, Joseph A. Affirmative action that works: a minority internship. Library Personnel News 2(2) 1988 27-28. 
451. Bonnichon, Monique. El formador: elemento clave del desarrollo de los sistemas de información AGRIS y CARIS. Revista AIBDA 9(1) 1988 55-63.

452. ChANDRA, Harish. Need for functional training programmes to meet challenges of modernization in engineering libraries: some reflections. In C.P. Vashishth, ed. Modernisation in Libraries. Seminar Papers, 33rd All-India Library Conference 1987. Delhi: Indian Library Association, 1988. ISBN 818521618 5. pp. 189-195.

453. Chisholm, Margaret E. Visionary leaders for 2020: developing leadership in human resources for library and information science. Illinois Libraries 70(8) 1988 $544-549$.

454. Davies, J. Eric. The importance of spreading the word: the Data Protection Act and staff training. Training and Education 5(1) 1987/88 3-22.

455. Du Plessis, Felicity. Serving the community 2: some impressions of the training course. Cape Librarian 32(7) 1988 13-15.

456. Downing, Alice. Training conservators in Western Ireland. Library Conservation News No. 2119883.

457. Grune, Siegfried. Aktuelle Probleme des Leihverkehrs Forbildungs-veranstaltung der FHBD in Köln in Zussamenarbeit mit dem Verband der Bibliotheken des Landes Nordrhein-Westfalen. Mitt. Verb. Bib. Land. Nord. 38(1) 1988 41-43.

458. Henson, Stephen and StefFenson, Martin. A government documents internship program for reference librarians. Southeastern Librarian 38(4) 1988 151-153.

459. Hva slags bibliotekledere trenger vi til dagens og morgendagens utfordringer? Synopsis 19(5) 1988 235-237.

460. Intern programs provide special focus for new grads. Library Personnel News 2(2) $198826-27$.

461. KeLLeR, Cecy. CLEM Coordinating Council offers program and training. Crab 17(4) 198813.

462. Launo, Ritva and Karivalo, Merja. Information Resources Management (IRM) in a companies training model. Int. J. Inf. Man. 8(2) 1988 141-144.

463. LAwSON, Bridget. Training and development in public library management. Inf. \& Lib. Man 7(4) 1988 88-90.

464. Lim, Edward Huck Tee. The CDS/ISIS training course: a brief report. Education for Information 6(2) 1988216.

465. LIM, Edward Huck Tee. USM/IDRC Regional Training Course on Library Automation. [Report] Education for Information 6(2) 1988 213-215.

466. Malan, Christine. Is Kaapland se bibliotekarisse opgewasse vir nuwe vitdagings? Cape Librarian 32(7) 1988 9-12. 
467. Mandillo, Anna Maria. La formazione nel Ministero per i beni culturali. AIB Boll. Inf. 28(1-2) 1988 81-89.

468. Minton, James C. Internship programs in an academic map library. Inf. Bull. West. Ass. Map Lib. 19(3) 1988 161-164.

469. Morris, Beryl. Meeting the challenge: the implications of the Great Education Reform Bill. Inf. \& Lib. Man. 7(4) 1988 91-93.

470. A new venture in inquiry training. ABN News No. 3719885.

471. O'Donnell, Peggy. Public Library Development Programme manual for trainers. Chicago: American Library Association, 1988. ISBN 0838933475.

472. Pringle, Cathy and Sharpe, Dave. Staff training in public libraries. Assignation 6(1) 1988 29-31.

473. Ramanaiah, K. Computer applications and manpower training in university libraries. In C.P. Vashishth, ed. Moderrnisation in Libraries. Seminar Papers, 33rd All-India Library Conference, 1987. Delhi: Indian Library Association, 1988. ISBN 818521681 5. pp. 196-201.

474. REDFIELD, Gretchen. Workshop alert: how to be prepared to give an effective workshop. Colorado Libraries 14(3) 1988 15-16.

475. RISTAU, Holly. Keep your shelves in order: techniques for training pages. School Library Journal 34(9) 1988 39-43.

476. RoBinson, E.J. Interpersonal communication skills training for new junior staff at the University of London Library. Lib. Bull. ULLRCC No. 42-43 1988 15-17.

477. Rosenberg, Diana and O'ConNoR, Brigid. Training at the grassroots: an integrated approach to the training of library assistants in the Southern Sudan. Information Trends-News Magazine 1(1) 1988 5-21. Another version of this article can be found in Information Development 4(1) 1988 14-21.

478. ShUTER, Janet. Training library workers in posts graded non-professional. Assignation 6(1) 1988 26-28.

479. STRICKLAND, Muriel. Map collection internship programs: an instructional role for the university map librarian: the San Diego experience. Inf. Bull. West. Ass. Map Lib. 19 (3) 1988 165-167.

480. Teasley, M.D. Reflections on the Certified Public Manager program: short and long term benefits. J. Educ. Lib. \& Inf. Sci. 28(4) 1988 290-293.

481. A training cooperative in practice: report of the South West Regional Training Officer's Group Annual Training Conference, 19th October 1987. Lib. Ass. Rec. 90(7) 1988 399-400.

482. TURNER, Philip M. In-service and the school library media specialist: what works and what doesn't. Sch. Lib. Med. Q. 16(2) 1988 106-109. 
483. VAN BRAKEL, P.A. Indiensopleiding vir intydse inligtingherwinning deur middel van rekenaarondersteunde onderrig. S. Afr. J. Lib. \& Inf. Sci. 56(1) 1988 18-26.

484. WARD, Alan. One week training courses in sound archives run by the British Association of Sound Collections (IASA UK). Phonographic Bulletin No. 501988 $15-25$.

485. WebB, Gisela M. Affirmative action internship program at the Texas Tech University Libraries. Lib. Admin. \& Man. 2(3) 1988 125-127.

486. WeBB, Gisela M. Preparing staff for participative management. Wilson Library Bulletin 62(9) 1988 50-52.

487. Willard, Patricia. Human relations in library education: developing and maintaining good relations with users. In Procs. IFLA General Conference, 54th, Sydney, 1988 (Paper 51-TRAIN-1-E).

488. WilseY, Charlotte. Public librarians trained for better reference service. Crab 17(4) 19885.

\section{ROLE OF ASSOCIATIONS AND SOCIETIES IN LIBRARY EDUCATION}

489. Heim, Kathleen M. and Simpson, Janice. Association for Library and Information Science Education. In ALA Yearbook of library and information services. Vol. 13. Chicago: American Library Association, 1988. ISBN 083890489 0. pp. 52-54.

490. Webrer, Sheila. The Institute of Information Scientists: training and education activities. Assignation 6(1) 1988 32-33.

491. Williams, Martha E. ASIS 2000: a vision, a hope and a plan. Bull. Amer. Soc. Inf. Sci. 15(2) 1988/89 28-29.

492. Williams, Martha E. Defining information science and the role of ASIS. [Presidential address]. Bull. Amer. Soc. Inf. Sci. 14(2) 1987/88 17-19.

\section{EDUCATION AND TRAINING FOR RELATED OCCUPATIONS}

493. ADAM, A.T. De vorming van archiefregistratoren en de S.O.D. opleiding. Bibliotheek \& Archiefgids 64(1) 1988 50-60.

494. Ball, Marion J., Douglas, Judith V. and Lunin, Lois F. Informatics and education in the health professions. J. Amer. Soc. Inf. Sci. 39(5) 1988 344-347.

495. Blank, Mark M. and BarRatT, David. Finding and selecting systems analysts and designers. Journal of Systems Management 39(3) 1988 8-11.

496. BRAZIER, Jan. The archivist: scholar or administrator? Archives and Manuscripts 16(1) 1988 9-14. 
497. BRICHFORD, Maynard. Who are the archivists and what do they do? American Archivist 51(1-2) 1988 106-110.

498. CooK, Michael. Records management at Liverpool: a commentary on an academic approach to the subject. Records Management Bulletin No. 241988 5-6.

499. Cox, Richard J. Educating archivists: speculations on the past, present and future. J. Amer. Soc. Inf. Sci. 39(5) 1988 340-343.

500. CRAWFORD, Marshall Jean. Information broking: a new career in information work. London: Library Association, 1988 (Library Association pamphlet, 41). ISBN 0853657181 .

501. DaVenPoRT, L. Information management: an educational perspective. Int. J. Inf. Man. 8(4) 1988 255-263.

502. Delcourt, Thomas. Training possibilities for sound archivists in France. Phonographic Bulletin No. 501988 12-14.

503. Delmas, Bruno. Trente ans d'enseignement de l'archiviste en France. La Gazette des Archives No. 141 1988 19-33.

504. EsSER, Mark. North Bennet Street School Bookbinding Course graduates first class. Conservation Administration News No. 35 1988 10-11.

505. Freeman, Carla Conrad. Viszualizing art: an overview of the visual resources profession in the United States. Art Documentation 7(1) 1988 6-8.

506. HARRISON, Helen P. Notes for training committee open session at the IASA Conference in Amsterdam, June 1987. Phonographic Bulletin No. 501988 2-6.

507. Holland, R.J. Post-graduate courses in Information Management and related areas. Int J. Inf. Man. 8(2) 1988 93-105.

508. Hubert, Rainer. Training possibilities for audio-visual media archivists. Phonographic Bulletin No. 501988 7-11.

509. JohNSTONE, I.J. ESARBICA's regional conservation course and seminar, Harare, Zimbabwe, 1-18 and 22-25 February 1988. [Report]. Int. Coun. Arch. Bull. No. 301988 16-18.

510. JoYCE, William L. Archival education: two fables. American Archivist 51(1-2) 1988 16-22.

511. LEE, Frank. Expanding your base: the law librarian as records manager. Law Library Journal 80(1) 1988 123-129.

512. LogAN, Edwin. Status and trends in graduate degree programs. Tech Trends 33 (4) 1988 8-10.

513. LyTLE, Richard H. Information Resource Management: research, education and practice. J. Amer. Soc. Inf. Sci. 39(5) 1988 337-339. 
514. MilLER, Sally McIntosh. North Bennet Street School. New Library Scene 7(2) $19881,5-6$.

515. OHNo, Atsushi. Training for informatization. Japan Computing Quarterly No. 721988 10-21.

516. PÉtusDótTIR, Kristin H. Skjala- og upplýsingastjórn. Bokasafnid 11 og 121988 $52-54$.

517. Puissant, Maria Julia. The School for Book Restoration at the Centro del Bel Libro, Ascona, Switzerland. Restaurator 9(1) 1988 37-50.

518. SmalletZ, Karen. Information brokering. Bull. Amer. Soc. Inf. Sci. 14(4) 1988 28.

519. Smalletz, Karen. Records management. Bull. Amer. Soc. Inf. Sci. 15(1) 1988 16.

520. Smith, Chris. Changing of the records manager. Int. Rec. Man. J. 4(1) 1988 9-11.

521. Southwood, Graham. Records management in Britain. Int. Rec. Man. J. 4(1) 1988 18-19.

522. TAYLOR, Hugh A. Transformation in the archives: technological adjustment or paradigm shift? Archivaria No. 25 1987/88 12-28.

523. Vanselow, Berthold, Neubacher, Thomas and Kreimes, Joachim. Training of graduates for information assistants in the context of information management. In H.J. Bullinger et al. eds. EUROINFO 88, 1st European Conference on Information Technology for Organizational Systems, Athens, 1988. Amsterdam: North-Holland, 1988. ISBN 044470427 2. pp. 144-147.

524. WeBER, Lisa B. Educating archivists for automation. Library Trends 36(3) 1988 501-518.

525. Wettstein, Emil. Informatik-Ausbildung an öffentlichen Schulen. Technica 37(4) 1988 36-37.

526. ZaPPALA, Antonio. Instruction in 'Book Restoration' in the Graduate Course in Conservation of Cultural Property at the University of Udine, Udine, Italy. Restaurator 9(1) 1988 27-36.

\section{EMPLOYMENT MARKETPLACE}

527. BENNETT, J.C. The charge of the library brigade: recruits to the profession are being misled by 'wildly improbable' reports of a librarian shortage. American Libraries 19 (8) 1988 724-725.

528. BERRY, John. The shortage of librarians is back. [Editorial]. Library Journal 113(9) 19884. 
529. Bischoff-Kummel, Gudrun and Feller, Antze. Am Ende der Schlange: Berufsanfänger/innen 1987. Bibliotheksdienst 22(1) 1988 8-11.

530. BolDEs, Felipe R. Information consultancy in Argentina-a limited profession. Online 12(4) 1988 49-51.

531. Brooks, Diane. Job-hunting in the UK. Canadian Library Journal 45(6) 1988 374-378.

532. BRustman, Mary Jane and VIA, Barbara J. Employment and status of part-time librarians in U.S. academic libraries. J. Acad. Lib. 14(2) 1988 87-91.

533. DavenPort, Lizzie and Cronin, Blaise. Demand and supply in information work. Education for Information 6(1) 1988 61-70.

534. GaUghan, Thomas M. A job seeker's market for librarians: growing number of vacancies prompt recruitment drives. American Libraries 19(3) 1988 180-181.

535. GREENE, Gloria and RoBb, Reive. Information scientists in the English-speaking Caribbean: challenges and responses in the development process. Libri 38(4) 1988 257-280.

536. HANNABUSS, Stuart. Manpower planning and information work: a survey and checklist. Inf. \& Lib. Man. 7(5) 1988 129-131.

537. HARRIS, Roma M. and ReID, K. Joanne. Career opportunities in library and information science: an analysis of Canadian job advertisements in the 1980s. Can. J. Inf. Sci. 13(1-2) 1988 17-29.

538. Hill, Susan. Employment trends: what are employers looking for? In H. Dyer \& G. Tseng, eds. New horizons for the information profession: meeting the challenge of change. Procs. Annual Conference Institute of Information Scientists Warwick, 1987. London: Taylor Graham, 1988. ISBN 094756832 8. pp. 207-211.

539. Holmes, P.L. The information industry. Aslib Information 16(2) 198838.

540. Kelly, Geoffrey. The self-employed historical researcher. Inf. \& Lib. Man. 7(5) 1988 113-115.

541. KendRICK, Terry. 'He not busy being born is busy dying'. Inf. \& Lib. Man. 7(5) 1988 117-119.

542. Learmont, Carol L. and Van Houten, Stephen. Placements and salaries, 1986: an upswing. In Bowker annual of Library and book trade information 33rd ed. New York: Bowker, 1988. ISBN 083522468 6. pp. 289-305.

543. Learmont, Carol L. and Van Houten, Stephen. Placements and salaries, 1987: the upswing continues. Library journal 113(17) 1988 29-36.

544. LYNCH, Mary Jo. ALA publishes 1988 salary data. American Libraries 19(10) 1988 887-888. 
545. Moorbath, Paul. Library vacancies 1985-87:P a sideways look. Lib. Ass. Rec. 90(6) 1988 335-336, 339.

546. MOORE, Nick. Information-intensive management and the expanding market for information professionals. Aslib Proceedings 40(9) 1988 255-259.

547. MOORE, Nick. Information-intensive management: impact on the employment market for information professionals. London: Aslib; Birmingham: Birmingham Polytechnic, 1988. ISBN 0851422365.

548. MYERS, Margaret. Guide to library placement sources. In Bowker annual of library and book trade information. 33rd ed. New York: Bowker, 1988. ISBN 0 83522468 6. pp. 271-289.

549. PresChel, Barbara M. Education of the information professional: what employers want. J. Amer. Soc. Inf. Sci. 39(5) 1988 358-361.

550. Pugh, Simon. 'Please write any further information in support of your application.' Some experiences of job hunting. Inf. \& Lib. Man 7(4) 1988 98-101.

551. Rochester, Maxine $\mathrm{K}$. The library and information services market in Australia. Educ. Lib. Aust. 5(2) 1988 111-119.

552. RoDWELl, Daphne. Information brokers: a place in the future information market. In H. Dyer and G. Tseng, eds. New horizons for the information profession: meeting the challenge of change. Procs. Annual Conference Institute of Information Scientists, Warwick, 1987. London: Taylor Graham, 1988 ISBN 0 94756832 8. pp. 138-143.

553. RUSE, David. Library manpower. In D.W. Bromley and A.M. Allott, eds. British librarianship and information work 1981-1985. Vol. 1. London: Library Association, 1988. ISBN 085365557 X. pp. 259-273.

554. Seavey, Charles A. Tennyson, crunching numbers and the state of the job market. American Libraries 19(11) 1988 946-947.

555. Sellberg, Roxanne. Two-year Master's degree programs and salaries of new library school graduates. J. Acad. Lib. 13 (6) 1988 336-339.

556. Three views of an unemployment group. Lib. Ass. Rec. 90(7) 1988398.

557. Trends in professional employment. CLR Reports 2(1) 1988 1, 3.

558. Tunstill, Cathy. Alternative bookselling. Inf. \& Lib. Man. 7(5) 1988 110-112.

559. Van Camp, Ann J. How to find a job online. Online 12(4) 1988 26-30.

560. VICKERS, Peter. Information consultancy in the UK-a growing profession. Online 12(4) 1988 42-44.

561. WeBb, Gisela M. Strategies for recruiting technical services personnel. Technicalities 8 (1) 1988 13-15. 
562. Woodsworth, Anne. Libraries and the Chief Information Officer: implications and trends. Library Hi Tech 6 (1) 1988 37-44.

563. WootLIFF, Veronica. Information brokering in the UK: an untapped market. Online 12 (4) 1988 44-46.

564. WRIGHT, Joyce C. Job opportunities for academic and public librarians: 1980-1984. J. Lib. Admin. 9(2) 1988 45-58. 


\section{NAME INDEX}

Aaron, S.L., 445

AASL, see American Association of Schoo Librarians

Abidi, S.A.H., 361

ABN, see Australian Bibliographic Network

Acevedo, A., 136

Adam, A.T., 493

Aelberts-Van de Ven, D.C.A., 128

AGRIS, 451

Ahmadu Bello University, Department of Library Science, 208

Ajlouni, T., 126

Al-Hajrasy, S., 013

Al-Sabagh, I.A.W., 446

Albino Andrade, M.E., 327

Aleamoni, L.M., 246

Alire, C., 036

ALISE, see Association for Library and Information Science Education

All-India Library Conference, 33rd., 1987, 119, $195,257,260,308,310,452,473$

Allott, A.M., 027, 060, 553

Alnaes, T., 139

Alqudsi-Ghabra, T., 089

ALSC, see Association for Library Service to Children

Aman, M.M., 037

American Association of School Librarians, 421

American Library Association, 289, 341, 429, 471,544

American Society for Information Science, 491, 492

Anderson, J.D., 363

Andrade, M.E. Albino, see Albino Andrade, M.E.

Andreyeva, I.M., 167

Anuradha, M., 310

ARLIS (UK) Education Committee, 263

ASIS, see American Society for Information Science

Aslib, 417, 441

Asp, W.G., 409

Association for Library and Information Science Education, 163, 339, 343, 489

Association for Library Service to Children, Education Committee, 267
Aurora (Colorado) Public Library, 402

Australian Bibliographic Network, 470

Australian Libraries Summit, Canberra, 1988, 038

Bačuvčiková, J., 107

Ball, M.J., 494

Bansal, G.C., 117

Barratt, D., 495

Bartczak, J., 350

Bayero University, Kano, 315

Beattie, K., 092

Bednarek, I., 447

Belánye, B. Bobok, see Bobok-Belánye, B.

Bellardo, T., 039

Bellingiri, L., 121

Benediktsson, D., 018

Bennett, J.C., 527

Berry, J., 528

Bertland, L.H., 421

Bewley, L., 103

Bierbaum, E.G., 268, 301

Biggs, M., 197

Birmingham, M.T., 410

Bischoff-Kümmel, G., 529

Blackie, E., 198

Blank, M.M., 495

Blanksby, M., 436

BLCMP, 349

Bloch, T., 136

Bobok-Belánye, B., $449^{\circ}$

Boissé, J.A., 450

Boldes, F.R., 530

Bonnichon, M., 451

Bookstein, A., 197

Borisov, B.V., 186

Boumarafi, B.B., 088, 187

Bowden, R., 110, 158

Bowman, R.J., 216

Boyce, B.R., 249, 329, 336

Brakel, P.A. van, see Van Brakel, P.A.

Brazier, J., 496

Brewer, J.G., 426

Brichford, M., 497

Bridgebuilders Collective, see $\mathrm{Na}$ Te Ropu Takawaenga

British Association of Sound Collections, 484 
British Library, Document Supply Centre, 443 British Library, Research and Development Department, 029

Broadbent, M., 093, 094

Bromley, D.W., 027, 060, 553

Brooks, D., 531

Brustman, M.J., 532

Bryant, S. Lacey, see Lacey Bryant, S.

Budd, J.M., 352

Bueno, J., 217

Bullinger, H.J., 523

California Library School Recruitment Project, 358

Camp, A.J. van, see Van Camp, A.J.

Campello, B. Santos, see Santos Campello, B.

Caproni, A.M., 122

Cargill, J., 388

CARIS, 451

Carpenter, R.L., 179

Carrigan, D., 337

Carver, D.A., 437

CDS/ISIS, 464

Centre de Recherche Retrospective, Marseille, 244

Centro del Bel Libro, Ascona, 517

Chandra, H., 452

Chaudhry, A.S., 090

Chernyak, A.Y., 168

China Society of Library Science Seminar 1986, 079

Chisholm, M.E., 453

Chobot, M.C., 411

Chulalongkorn University, Department of Library Science, 199

City of Birmingham Polytechnic, Library School, 181, 206, 328, 349

City University, Department of Information Science, Silver Jubilee Conference 1987, 071, 075, 212

Clark, A.J., 001

Clark, S.M., 274

Clegg, H., 389

CLEM, see Continuing Library Education in Maryland

CLENE, see Continuing Library Education Network and Exchange

Clyde, L.A., 231

Coadic, Y. le, see Le Coadic, Y.

College of Librarianship Wales, 012, 110, 207, $320,348,408$

College of Librarianship Wales, Library, 012

Columbia University, School of Library Services, $031,034,279$
Concordia University, 234

Condron, B.J., 200

Continuing Library Education in Maryland, 461

Continuing Library Education Network and Exchange Round Table, 409

Conway, P., 353

Cook, M., 498

Cooper, M., 068

Corbin, J., 040

Cordonier, J., 041

Correia, A.M.R., 151

Courrier, Y., 042, 043

Cox, R.J., 499

Craft, A.H., 432

Craig, D., 232

Crasta, M., 292

Crawford, G.A., 241

Crawford, M.J., 500

Cronin, B., 044, 045, 533

Dartnall, J., 311

Data Protection Act (UK), 454

Davenport, L., 501, 533

Davies, J.E., 454

Dawson, A., 364

Day, J.M., 242, 243

De Faunce, M.C., 046

De Figueiredo, N.M., 101

Delcourt, T., 502

Delmas, B., 503

Dembowska, M., 147

Dempsey, L., 181

Deogan, M.S., 293

Devarajan, G., 019

Dewey, M., 031, 032

Dosa, M.L., 047-050, 188

Dou, H., 244

Douglas, J.V., 494

Downing, A., 456

Doyle-Wilch, B., 160

Dresden Technical University, Information Department, 306

Drexel University, College of Information Studies, 373

Du Plessis, F., 455

Dyer, H., 045, 305, 538, 552

Dzharylgasova, S.K., 169

Ealing College of Higher Education, School of Library and Information Studies, 201

East, H., 020, 021

East African School of Librarianship, 361

East Sussex County Library Service, 403

Eastern and Southern African Regional Bureau of the International Council on Archives, 509 
Education Reform Bill (UK), 469

Elepov, B.S., 170

Elkin, J., 354

Ellis, D., 196, 203, 300

Erzsébet, T.N., 245

ESARBICA, see Eastern and Southern African Regional Branch of the International Council on Archives

Essen Symposium, 1987, 316

Esser, M., 504

EUROINFO '88, 523

Evans, J., 144-146, 285

Ezell, C., 340

Farrow, C., 129, 365

Faunce, M.C. de, see De Faunce, M.C.

Feather, J., 313, 414

Feller, A., 529

Ferligoj, A., 006

FID, Education and Training Committee, 047, 049

Figueiredo, N.M. de, see De Figueiredo, N.M.

Fischbach, G., 114

Flinspach, K. Holste-, see Holste-Flinspach, K.

Flood, B.J., 161

Foggin, C.M., 390

Foster, W., 181, 349

Francis, S., 102

Frederik Muller Academie, 365

Freeman, C.C., 505

Freimer, G., 422

Frick, E., 330

Froehlich, T.J., 047, 049

Galler, A.M., 234

Garrison, G., 051

Gash, S., 189

Gaughan, T.M., 534

Gebolys, Z., 278

Gelfand, J., 272

General Information Programme, Ad Hoc Committee on Education and Training, 035

Geretto, P., 438

Getz, M., 439

Ghabra, T. Alqudsi-, see Alqudsi-Ghabra, T.

Ghaqda Bibliotekarji, 382

Gibbons, F., 099

Gibson, R., 296

Giraud, O., 264

Godden, I., 200

Goodell, J., 302

Goodfellow, R.A.H., 393

Gorman, G.E., 052

Gothberg, H.M., 246

Gracy II, D.B., 338
Greene, G., 535

Greguletz, A., 053

Greiner, J.M., 391

Grune, S., 457

Haas, W.J., 054

Hajrasy, S. Al-, see Al-Hajrasy, S.

Hallein, J., 286

Hannabus, S., 247, 536

Hansen, K.B., 141

Harare Polytechnic, Department of Library and Information Studies, 229

Harding, C., 320

Hariri, M., 120

Harris, R.M., 405, 537

Harrison, C.T., 375

Harrison, H.P., 506

Hartman, S.E., 415

Harvey, R., 314

Hassanaly, P., 244

Havard-Williams, P., 100

Hayes, R.M., 055, 182

Haythornthwaite, J., 088

Heim, K.M., 329, 339, 355, 489

Heine, M., 022

Helal, A.H., 316

Hellen, B., 440

Hempstead, J., 287

Henson, S., 458

Hepworth, J.B., 318

Hewlett, J., 376, 377

High Plains Regional Library Service System, 419

Hill, M.W., 023

Hill, S., 538

Hillier, A., 408

Hogg, F.N., 348

Holland, R.J., 507

Holmes, P.L., 539

Holste-Flinspach, K., 115

Horton, F.W., 056

House, N.A. van, see Van House, N.A.

Houser, L., 014

Houten, S. van, see Van Houten, S.

Howard, H., 104

Howden, N., 248, 249

Hubert, R., 508

Hug, W.E., 288

Hulme, A.J., 392

Hulse, R., 098

Humboldt Universität, Institut für Bibliothekswissenschaft und wissenschaftliche Information, 362

Hurd, J.M., 057 
Hussein, D., 120

Hyland, M., 218

IASA, see International Association of Sound Archives

IASA (UK), see British Association of Sound Collections

Ibrahim, M.Z., 315

IDRC, see International Development Research Centre

IFLA, 096

IFLA/China Society of Library Science Seminar 1986, 079

IFLA Continuing Professional Education Round Table, 416

IFLA General Conference, 52nd, Tokyo 1986, 073

IFLA General Conference, 53rd, Brighton 1987, 058, 062, 086, 413

IFLA General Conference, 54th, Sydney 1988, $042,074,102,346,411,423,487$

IFLA Section of Education and Training, 037, 058, 059

Indiana Library School, 033

INFO, 259

Institute of Information Scientists, 389, 490

Institute of Information Scientists, Conference 1987, 045, 538, 552

INSTRUCT, 261

International Association of Sound Archives, Round Table on Curriculum Development, 506

International Development Research Centre, 066, 465

IRANDOC, 120

Ireland, R., 320

Jarocin State Library Institute, 350, 372

Järvelin, K., 015

Jespersen, S., 417

Joel, A., 233

Johnston, S., 131

Johnstone, I.J., 509

Joint Annual Study Conference, COFHE and Education Libraries Group,1987, 426

Jolivet, L.C., 280

Jones, D., 060

Jordan Library Association, 126

Joyce, W.L., 510

Kaegbein, P., 061-063

Kajberg, L., 366-367, 418

Kansas Library Continuing Education Needs Assessment Survey, 430

Karetzy, S., 250

Karivalo, M., 462
Kaula, P.N., 030

Kaula Award, 348

Kawatra, P.S., 064

Kaye, D., 299

Keller, C., 461

Kelly, G., 540

Kendrick, T., 541

Kerham, A.S., 219

Khoo, S.M., 204

Kichigina, V., 171

Kirkham, S., 251

Klyuyev, V.K., 172

Knepel, N., 419

Kong, L.M., 393

Korytnyk, C.A., 024

Kozakiewicz, W., 265

Kriemes, J., 523

Kriessman, B., 391

Krogt, P.C.J. van der, 273

Kroken, G.T., 142

Kumar, P.S.G., 118, 119

Kumar, R.P., 275

Kümmel, G. Bischoff, see Bischoff-Kümmell, G.

Kuring-gai College of Advanced Education, 335

Laaksovirta, T., 111

Lacey Bryant, S., 394

Lajeunesse, M., 368

Laney, E.J., 190

Large, J.A., 191

Latham, E., 025

Launo, R., 462

Lawson, B., 463

Le Coadic, Y., 065

Learmont, C., 542, 543

Lee, F., 511

Leide, J.E., 026

Leitch, E., 442

Lendvay, O., 066

Lenox, M.F., 340

Lester, J., 182

Lewis, D., 067

Li, C.Q., 105

LIBEX, 408

Library Association (UK), 159, 351, 375-377, 381, 383, 385, 398

Library Association of Australia, 374, 378

Lim, E.H.T., 464, 465

Liverpool Polytechnic School of Librarianship and Information Studies, 258

Liverpool University, 498

Locke, J., 234

Lockett, M., 281

Logan, E., 512 
Loughridge, B., 316, 395

Louisiana Tech University, 458

Louisiana State University, Library and Information Science Library, 364

Louw, A., 369

Lunin, L.F., 068, 494

Lusher, A., 313

Lynch, M.J., 341, 544

Lytle, R.H., 513

Mahmoodi, S.H., 410

Majima, H., 443

Malan, C., 466

Mancall, J.C., 421

Manchester Polytechnic Department of Library and Information Studies, 259, 299

Mandillo, A.M., 192, 467

Marchand, D.A., 371

Markham, C., 224

Martin, G., 252

Martin, S.C., 396

Martin, W.J., 342

Mascioni, M., 253

Massissimo, A., 157

Mayol, M.C., 157

McCabe, G.B., 391

McClean, M., 180

McCrossan, J.A., 420

McGarry, K., 069, 205

McKee, B., 070, 206

McLean, D.D., 422

Meadows, A.T., 071

Medical Library Association, 384

MEILLEUR, 110

Mejzhis, I.A., 173

Menou, M.J., 101

Mercer, P.A. Yates-, see Yates-Mercer, P.A

Merryweather, J., 225

Merwe M.S. Van der, see Van der Merwe, M.S.

Merz, M., 397

Michalski, L., 148

Mihály, P., 245

Mihel, I., 006, 023

Miksa, F.L., 031

Miller, M.L., 289

Miller, S.McI., 514

Ming, M., 235, 282

Minton, J.O., 468

Moen, W.E., 355

Moi University, Faculty of Information Science, 370

Moll, J.K., 161

Monjau, D., 306

Moorbath, P., 545
Moore, N., 004, 027, 072, 546, 547

Moran, B.B., 343

Moravian College, 241

Morgan, P.B., 276

Morris, A., 193

Morris, B., 398, 469

Msiska, A.W.C., 127

Munthe, G., 032

Murray, C., 435

Musisi, J.S., 370

Myers, M., 548

$\mathrm{Na}$ Te Ropu Takawaenga, 130, 132

NALGO, 237, 238

Napier Polytechnic of Edinburgh, 232

Nassimbeni, M., 194

National Council for Accreditation of Teacher Education, 289

National Library of Canada, 254

Navalani, K., 308

Naylor, P., 221

NCATE, see National Council for Accreditation of Teacher Education

Neubacher, T., 523

Newark Public Library. Certified Public Manager Program, 480

Newcastle-upon-Tyne Polytechnic. Department of Librarianship and Information Studies, 022, 242-243

NHS Regional Librarians Group and University Medical School Librarians Group, Joint Training Sub-Committee, 377

Nicholson, F., 344

North Bennet Street School, Boston, 504, 514

Norway, National Office of Research and Special Libraries, 459

Norwegian Library Association, 140

Norwegian School of Library and Information Science, 002, 003, 139, 140

Nyhan, C.W., 358

Nzotta, B.C., 138

O'Connor, B., 477

O'Donnell, P., 471

O'Donovan, K., 243

O’Neill, M., 193

Ochogwu, M.G., 137

Ohno, A., 515

Onadiran, G.T., 208

Online Public Access to Library Files, Conference, 3rd, 1987, 181

Orden, P. van, see Van Orden, P.,

Oudegroeniger, B., 255

Ozarchuk, L.V., 174

Pachman, F.C., 277 
Panjab University (Lahore), 117

Paris, M., 183, 184

Parmer, C., 005

Passet, J.E., 033

Pateman, J., 399

Paul, D., 271

Pearson, R.C., 356

Perritt, P.H., 379, 380

Pétursdóttir, K.H., 516

Pettus, E.S., 209-211

Phillips, J.C., 422

Phillips, S., 423

Pikes Peak Community College, 217

Pindlowa, W., 106

Plessis, F. du, see Du Plessis, F.

Polytechnic of North London, School of Librarianship and Information Studies, 205

Pontificia Universidad Javeriana, Departamento de Bibliotecologia, 155

Poole, A., 381

Powell, R.R., 424

Preschel, B.M., 549

Prevot, M., 256

Pringle, C., 472

Prüfer, C., 307

Public Library Development Programme, 471

Pugh, S., 550

Puissant, M.J., 517

Queens University Belfast, Department of Information Studies, 342

Queensland Institute of Technology, Department of Information Systems, 213, 359

Quirk, M. Sandow-, see Sandow-Quirk, M.

Quoniam, L., 244

Raju, A.A.N., 195

Rahman, A., 297

Ramanaiah, K., 473

Rao, G. Surya, see Surya Rao, G.

Ratmanova, S.B., 169

Rayward, W.B., 095

Reardon, D.F., 189

Reddy, J.Y., 257

Redfield, G., 474

Reid, K.J., 537

Reid-Smith, E.R., 096

Revill, D.H., 258

Riksbibliotekjenesten (Norway), 448

Ristau, H., 475

Ritchie, S., 321, 400

Robayo, M.P., 155

Robb, R., 535

Robbins, J., 162

Roberts, N., 300
Robertson, S.E., 212

Robinson, E.J., 476

Rochester, M.K., 073, 551

Rodwell, D., 552

Rolland-Thomas, P., 074

Ronnie, M.A., 133

Rosenberg, D., 477

Rowley, J.E., 259

Royal Melbourne Institute of Technology, Department of Information Services, 094

Royal School of Librarianship, Copenhagen, 366-367, 418

Rugaas, B., 143

Rural Library Training Project, see Southern Alberta Institute of Technology, Rural Library Training Project

Ruse, D., 553

Rutgers State University of New Jersey, School of Communication, Information and Library Studies, 363

Rux, P., 401

Sabagh, I.A.W. Al-, see Al-Sabagh, I.A.W.

Sable, M.H., 016, 357

Sanders, R., 097

Sandow-Quirk, M., 213

Santos Campello, B., 327

Saunders, W., 130-135,

Savard, R., 326, 368

Savolainen, R., 017

Scarborough, K., 358

Schwartz, D.G., 332

Schwarz, S., 006

Scott, E.J., 075

Seader, J., 269

Seavey, C.A., 274

Seavey, C.J., 554

Sebastiani, M., 121

Segal, B., 402

Seibel, B., 076

Sellberg, R., 303, 555

Sercombe, L., 222

Settel, B., 371

Shapiro, E.L., 298

Sharpe, D., 472

Shaughnessy, T.W., 425

Sheldon, B.E., 077

Shimmon, R., 383, 426

Shuter, J., 478

Sidhu, M.S., 308

Silovic, N. Tudor-, see Tudor-Silovic, N.

Simonov, B.A., 262

Simpson, J., 489

Singh, S., 260, 309 
Sinkiavičus, K.A., 175

Sippings, G., 078, 441

Slater, M., 427

Sleszenko, J., 149

Slinger, M.J., 270

Slyadneva, N.A., 167

Smalletz, K., 518, 519

Smith, C.M., 403, 520

Smith, E.R. Reid-, see Reid-Smith, E.R.

Smith, I.A., 414

Smith, J., 237, 238

Smith, J.B., 428

Sneath, T.W., 163

Society of American Archivists, 338

Sokolov, A.B., 178

Sommer, S.J., 279

Sorensen, R.J., 429

South West Regional Training Officer's Group, Annual Training Conference 1987, 481

Southern Alberta Institute of Technology, Rural

Library Training Project, 235, 236

Southwood, G., 521

Stanke, N., 223

Starke, N.A., 430

Starre, J. Van der, see Van der Starre, J.

State Library Berlin, 294

Steele, D., 404

Steffenson, M., 458

Stone, E.W., 431

Strickland, M., 479

Strubbe, L.A., 332

Stueart, R.D., 346

Stuart, E.A., 333

Sullivan, P., 347

Surya Rao, G., 310

Sutton, J., 395

Swanepoel, A.J., 152

Syracuse University, 188, 371

Szepesváry T., 322

Szocki, J., 290

Tague, J., 405

Tameem, J.A., 007

Taylor, H.A., 522

Teasley, M.D., 480

Tees, M.H., 079, 080

Tejomurty, A., 028

Telford Collge, Edinburgh, 224, 233

Tereshin, V.I., 176

Texas Tech, University Libraries, 485

Thomas, P. Rolland-, see Rolland-Thomas, P.

Thomas, W.M., 334

Thompson, A., 110

Tikku, U.K., 117
Tilley, C.M., 284, 359

Torio, M., 125

Totten, H.L., 185

Transbinary Group on Librarianship and Information Studies, 158

Trapeznikova, L.V., 167

Tseng, G., 045, 538, 552

Tudor-Silovic, N., 006, 023

Tunstill, C., 558

Turner, J., 317

Turner, P.M., 482

Tutunnik, V.M., 186

TYGLIS, see Transbinary Group on Librarianship and Information Studies

Unisa, see University of South Africa

Universitätsbibliothek Essen, 316

Université de Montréal, Ecole de Bibliothéconomie et des Sciences de l'Information, 368

Universiti Sains Malaysia, 465

University College Dublin, Department of Library and Information Studies, 240

University College of Wales, Aberystwyth, Faculty of Law, 207, 320

University of Arizona, Graduate Library School, 246

University of Botswana, Department of Library Studies, 099, 100

University of California (Santa Barbara), Minority Internship Programme, 450

University of Kerala, Department of Library and Information Science, 309

University of London, Library, 476

University of Malta, Department of Librarianship and Information Studies, 202

University of Malaya, Institute of Advanced Studies, 204, 209-211

University of Michigan, School of Information and Library Studies, 332

University of Papua New Guinea, Department of Library and Information Studies, 146

University of Sheffield, Department of Information Studies, 196, 203, 392, 395

University of South Africa, Department of Library and Information Science, 239, 334, 369

University of Toledo, William S. Carlson Library, 422

University of Udine, 526

Usherwood, B., 283, 323, 328

Vakkari, P., 015

Van Brakel, P.A., 483

Van Camp, A.J., 559

Van de Ven, D.C.A. Aelberts-, see Aelberts-Van de Ven, D.C.A. 
Van Der Krogt, P.C.J., see Krogt, P.C.J. van der Van der Merwe, M.S., 239

Van der Starre, J., 365

Van House, N.A., 360

Van Houten, S., 542, 543

Van Orden, P., 164

Vanselow, B., 523

Vashishth, C.P., 119, 195, 257, 260, 308, 310, 452, 473

Vasilchenko, N.P., 177

Venkatappaiah, V., 348

Verho, S., 112

Vessey, S., 283

Via, B.J., 532

Vickers, P., 560

Victoria University of Wellington, Department of Librarianship, 130-135

Villanueva, C., 156

Vincent, I.C., 324

Visser, M.S.P., 153

Vodičková, H., 108

Vuoria, R., 113

Wade, S.J., 261

Walczak, M., 081, 150, 372

Wales, J., 082

Walker, C.M., 154

Waller, S., 256

Walter, R-E., 294

Walters, C., 214

Waluzyniec, H., 384

Ward, A., 484

Watkins, J.F., 432

Webb, G., 325, 485, 486, 561

Webb, T.D., 356

Webber, S., 490

Weber, L.B., 524

Weinberg, B.H., 304

Weingand, D., 433, 434

Weiss, J.W., 316

Wellington College of Education, 291

Wellington Teachers College, School of Library Studies, 130-135
Welsh Librarians' Training Group, 444

Werner, R., 083, 116

Western Australia College of Advanced Education, 231

Westley, D.D., 109

Wettstein, E., 525

White, B., 029, 406

White, H.S., 165, 166, 215

Wilch, B Doyle-, see Doyle-Wilch, B.

Wilkinson, J., 435

Willard, P., 487

Willett, P., 261

William, N., 149

Williams, J., 320

Williams, M.E., 491, 492

Williams, P. Havard-, see Havard-Williams, P.

Williamson, J., 295

Williamson, L.E., 407

Wilsey, C., 488

Wilson, P., 085

Wilson, T.D., 300, 392

Wisconsin University at Madison, School of Library and Information Studies, 434

Wise, M.C.G., 408

Wood, F.E., 196, 319

Woodsworth, A., 562

Woodward, D., 373

Wooley, M., 385

Wootliff, V., 563

Wright, J.C., 564

Wroclaw State Cultural, Educational and Library Institute, 265

Yates-Mercer, P.A., 071, 075, 212

Yerbury, H., 335

Yivo Institute for Jewish Research, Max Weinrich Center for Advanced Jewish Studies, 304

Yocklunn, J., 087

Youngsuck, C., 336

Zappalá, A., 526

Zazersky, E.Y., 178

ZEPHYR, 240

Zhdanova, T.A., 170 


\section{SUBJECT INDEX}

Academic librarianship, 262, 332, 393, 422, 446, $450,458,468,476,479,485,532,557,564$

Accreditation, 008, 161, 185

Acquisitions work, teaching, 293 see also Collection development, teaching

Admissions, library schools, 351, 352, 354, 357, 358

Africa, 509

see also individual countries

Algeria, 088

Arab World, 089

see also individual countries

Archive management, 338, 484, 493, 496, 497, 499, 502, 503, 506, 508-510, 522, 524

see also Records management

Argentina, 530

Art librarianship, 263

Asia, 090

see also individual countries

Australasia, 091

see also individual countries

Associateship, 375-377, 385

Associations, see Library associations

Audiovisual archivists, 506, 508

Audiovisual librarianship, 264

Audiovisual materials, use in teaching, 260

Australia, 009, 038, 091-097, 213, 216, 218, 221, $222,231,284,286,302,311,314,335,344$, $359,374,378,423,470,496,551$

Bangladesh, 090, 297

Belize, 098

Bibliographic instruction, teaching, 330

Bibliographies, 001-007, 437, 440

Bibliography, teaching, 298

Bibliometric analysis, teaching, 244

Bibliotherapy, teaching, 265

Black librarians, 351, 354 see also Ethnic minority librarians see also Multicultural librarianship

Book restoration, teaching, 517, 526

Bookbinding, teaching, 504, 514

Bookselling (profession), 558

Botswana, 099, 100

Brazil, 101, 327

Brunei, 102

Burma, 090
Business information, teaching, 266, 299, 300 see also Business librarianship

Business librarianship, 266, 386 see also Business information, teaching

CAI, see Computers, use in teaching

CAL, see Computers, use in teaching

Canada, 025, 103, 104, 216, 234-236, 254, 282, 368, 384, 405, 433, 435, 537

Career choice, guidance, 357,360

Career development, 270, 386-408, 410 see also Continuing education see also Professional development

Career plateauing, 397

Caribbean, 535

Cataloguing, teaching, 239, 301-304

Cataloguing, training, see Cataloguing, teaching

CD-ROM, use in teaching, 242

Certificate courses, professional staff, 199 see also Professional staff, first qualification courses

Certification, medical librarians, 384

Certification, school library media specialists, 379,380

Chartering, see Associateship

Children's librarianship, 267

China, People's Republic, 090, 105, 106

Classification, teaching, 032, 239

Clerical staff, see Non-professional staff

Closures, library schools, 183, 184

Collection development, teaching, 279, 297, 449

Colombia, 155

Communication skills training, 476

Compact Disc-Read Only Memory, see CDROM

Comparative studies, 179, 180

Computer-Assisted Instruction, see Computers, use in teaching

Computer-Assisted Learning, see Computers, use in teaching

Computer skills, teaching, 244, 248, 306-310, 434, 473

Computers, use in teaching, 240, 245, 249, 251 $255,257,259,261,365$

see also Computer skills, teaching

see also Library automation, teaching

see also Library automation, training 
Conservation, teaching, 311-317, 456, 509, 517

Continuing education, $012,102,120,268,295$, 409-435

see also Career development

see also Professional development

Cooperative training, 481

Corporate information management, 045

Correspondence courses, see Distance learning

Courses, design of, see Curriculum development

Courses of study, see types of course, e.g. Professional staff, first qualification courses

Curriculum development, 006, 064, 085, 086, 090, $108,119,123,141,153,186-196,316,506$

Czechoslovakia, 107, 108

Data display panels, use in teaching, 252

Database management, teaching, 318

Database software, use in teaching, 259

Denmark, 109, 366, 367, 418

Developing countries, 066, 087, 275

Diploma courses, professional staff, 108, 202, 362

see also Professional staff, first qualification courses

Directories, 008-012, 548

Dissertations, 028 see also Doctoral theses

Distance education, see Distance learning

Distance learning, 201, 231-239, 413, 501 see also Continuing education

Doctoral theses, 024

East Germany, see German Democratic Republic

Educational technology (profession), 512

Eire, see Ireland, Republic of,

Employment marketplace, see Job market

Employment opportunities, see Job market

Employment seeking, see Job seeking

Entrance requirements, library schools, see Admissions, library schools

Equal opportunities (employment), 351

Equivalence (qualifications), 042, 080, 110

Ethnic minority librarians, 130, 132, 354, 450 see also Black librarians see also Multicultural librarianship

Europe, 110, 179, 523 see also individual countries

Expert systems, teaching, 193

Examinations, library school, 246

Exchanges, see Job exchanges

Faculty, see Lecturers, library school

Fieldwork, see Practical work experience

Finland, 111-113, 462

First qualification courses, see Professional staff, first qualification courses
France, 041, 065, 076, 180, 244, 256, 264, 502, 503

Francophone library education, 368

Funding, research, see Research funding

German Democratic Republic, 053, 083, 114-116, 226-228, 230, 306, 307, 331, 362

Germany, Federal Republic, 115, 180, 294, 457, 529

Government documents work training, see Official publications work, training

Harmonization of training, 042,080 see also Equivalence (qualifications)

Health sciences librarianship, see Medical \& health sciences librarianship

Hebraica cataloguing, teaching, 304

History, library education, 030-034, 105, 108, $111,118,122,345,372$

Historical research (profession), 540

Humanities librarianship, 251, 268

Hungary, 245, 322, 449

Iceland, 018,516

In-service training, see Training

India, 019, 028, 030, 064, 090, 117-119, 195, 257, $260,275,293,308-310,348,452,473$

Indonesia, 090

Informatics (profession), 515, 525

Information brokerage, see Information consultancy

Information consultancy, 500, 518, 530, 541, 552, 560,563

Information management, see Information resources management

Information resources management, 056, 067, $070,078,082,086,161,212,213,462,501$, $507,513,519,523,546,547,562$

Information retrieval, teaching, 240, 254, 255, $259,261,318,319$

Information science, teaching, $071,101,147,161$, 363,492

Information technology, 057, 079, 179, 212, 218, $251,257,307,365,434$ see also headings under Computer see also Library automation

Information work, teaching, see Reference work, teaching

Instructional technology (profession), see Educational technology (profession)

Intellectual property, teaching, 320

Inter-library lending, training, 457

International education, 048 see also Equivalence (qualifications) see also Study abroad

Internship, 332, 450, 458, 460, 468, 479, 485

IR, see Information retrieval 
Iran, 120

Ireland, Republic of, 240, 263, 456

IRM, see Information resources management

IT, see Information technology

Italy, 121-124, 192, 292, 438, 467, 526

Japan, 090, 125, 180, 515

Job exchanges, 110, 407, 408

see also Secondment

Job market, 004, 072, 110, 196, 390, 439, 527-564

see also Job seeking

Job seeking, 550, 559

see also Job market

Jordan, 126, 275, 446

Judaica cataloguing, teaching, 304

Kenya, 370

Latin America, 156 see also individual countries

Law librarianship, 269, 270, 320, 511

Lecturers, library school, 096, 107, 197, 309, 336-349

Librarianship (profession), characteristics, 076

Library and information profession, characteristics, 076

Library assistants, see Non-professional staff

Library associations \& other professional bodies, 037, 047, 049, 058, 059, 061-063, 096, 140, $163,338,339,341,343,351,374-378$, $381-385,398,421,429,441,445,489-492$

Library automation, teaching, 181, 255, 305, $307-310,464,465$

Library automation, training, 248, 308-310, 473

Library education, history, see History, library education

Library instruction, teaching, see Bibliographic instruction, teaching

Library / Library school cooperation, 243, 258

Library school lecturers, see Lecturers, library school

Library school libraries, 364

Library school students, see Students, library school

Library schools, 008, 030-034, 055, 084, 090, $096,107,116,125,128,138,139,141,146$, $152,155,181-185,249,254,258,259,300$, $303,312,313,316,330,337,342,349,352$, $361-373,395,533$

Library technicians, see Paraprofessional staff

Local studies librarianship, 271

Malawi, 127

Malaysia, 090, 204, 209-211, 464, 465

Malta, 202, 382

Management, teaching, 006, 093, 212, 321-325

Management training, 077, 321, 325, 448, 453, $459,463,486$
Manpower development, see Training

Manpower planning, 043, 536

Map librarianship, 272-274, 468, 479

Marketing, teaching, 243, 326

Masters courses, professional staff, 028, 197, 200-204, 209-212, 214, 215, 332, 355, 360, $392,395,555$

Material selection, see Acquisitions work

Media librarianship, see Audiovisual librarianship

Medical and health sciences librarianship, 275-277, 376, 377, 384, 494

Methods of teaching, see Teaching methods

Modular study, 191, 256

Multicultural librarianship, 130, 132, 280

see also Black librarianship see also Ethnic minority librarians

Museum librarianship, 268

Music librarianship, 278, 279

Netherlands, 128, 129, 255, 273, 365, 493

New Zealand, 130-135, 291

Nicaragua, 136

Nigeria, 137, 138, 208, 275, 315

Non-professional staff, career development, 387 , 396, 403

Non-professional staff, education, 115, 224-230, $232,233,235,237,238$

see also Non-professional staff, qualifications

Non-professional staff, qualifications, 224, 225, $229,232,233,237,238,381$ see also Non-professional staff, education

Non-professional staff, training, 475, 478

North America, see Canada and United States of America

Northern Ireland, 342

Norway, 002, 003, 139-143, 448, 459

Official publications work, training, 458

Online intermediaries, training, 242, 243, 250, $254,319,451,483$

Optical media, use in training, 253 see also CD-ROM, use in teaching

Pakistan, 090, 276, 414

Papua New Guinea, 144-146, 285

Paraprofessional staff, education, 005, 216-223, 426

Paraprofessional staff, qualifications, 383 see also Paraprofessional staff, education

Paraprofessional staff, training, 005, 222, 223, 426

Part-time employment, 532

Part-time study, 231-239, 273 see also Distance learning

Personnel skills, training, 487

Philippines, 090 
Philosophy of library education, 013-017

Poland, 081, 147-150, 265, 290, 350, 372, 447

Portugal, 151

Practical work experience, 041, 116, 294, $331-335,450$

see also Internships

Practical work experience, library school lecturers, 340

Preservation, teaching, see Conservation, teaching

Prisoners, training as librarians, 324

Professional development, 288, 292, 385, 389, $417,425,428,431,445,446$

see also Career development

see also Continuing education

Professional qualifications, 289, 374-385, see also Associateship

see also Certification

Professional staff, advanced education, 093, 102, $128,150,273,309$

Professional staff, first qualification courses, 009, $108,129,130-135,139,140,143,197-215$, $258,324,332,335,355,360,362,392,395$, $426,507,555$

Programming, teaching, 306

Public librarianship, 236, 267, 271, 280-283, 353, $391,399,402,403,415,419,420,430,455$, $463,466,471,472,480,481,488,564$

Publishing patterns, librarianship researchers, 024

Qualifications, see Professional qualifications

Rare book librarianship, 284

Records management, 493, 498, 511, 516, 520, 521

see also Archive management

Recruitment (employment), 534, 538, 542, 543, 548,561

Recruitment (library schools), see Admissions, library schools

Re-entry to job market, $390,394,398$

Reference work, teaching, 271, 327, 328, 458, 488

Research, 018-029, 058, 061-063, 079, 138, 366

Research funding, 020, 021

Research techniques, teaching, 138

Rural librarianship, 097, 235, 236, 282

Russia, see Union of Soviet Socialist Republics

Salaries, 542-544, 555

Saudi Arabia, 007

Scandinavia, see individual countries

Scholarships, 010, 011

School librarianship, 235, 236, 282, 285-291, 379, $380,421,432,445,482$

School library media personnel, see School librarianship
Scotland, 224, 232, 233, 442

Secondment, 110

see also Job exchanges

Selection, materials, teaching, see Acquisitions work, teaching

Selection, students, see Admissions, library schools

Sound archivists, 484, 502, 506

South Africa, Republic of, 152-154, 194, 219, $220,239,334,369,455,466,483$

South Korea, 090

Spain, 157

Special librarianship, 292-295, 385, 427, 452, 467

Sri Lanka, 090

Staff development, see Training

Staff training, see Training

Statistics, library education, 163

Stock management, teaching, see Collection development, teaching

Stock selection, teaching, see Acquisitions work, teaching

Students, library school, 152, 350-360, 529

Study abroad, 073

see also Equivalence (qualifications)

see also International education

Study tours, 333

Sub-professional staff, see Paraprofessional staff

Sudan, 477

Switzerland, 517, 525

Systems analysis (profession), 495

Systems analysis, teaching, 329

Systems design, teaching, 181, 193, 212

Teacher librarians, see School librarianship

Teaching methods, 057, 079, 179, 212, 218, $240-261$

Teaching staff, library schools, see Lecturers, library schools

Technical librarianship, see Special librarianship

Technical services personnel, job market, 561

Technicians, library, see Paraprofessional staff

Thailand, 090, 199

Theological librarianship, 296

Theory of library education, 013-017, 041

Theses, see Doctoral theses

Third World, see Developing countries

Three dimensional objects, cataloguing, 301

Training, general, 037, 047, 049, 059, 060, 083, $098,099,106,113,124,126,142,151,292$, $295,400,427,436-444,490$

Training, specialized, $077,212,241,308,310$, $321,325,332,376,377,445-448$

Training materials, 440

Tunisia, 275 
Uganda, 361

UK, see United Kingdom

Undergraduate courses, professional staff, 129, 139, 198, 205-208, 213, 328, 335

see also Professional staff, first qualification courses

Unemployment, 556

Union of Soviet Socialist Republics, 167-178, $186,262,298$

United Kingdom, 020-022, 027, 029, 044, 060, 069-071, 075, 084, 158,159,180,181, 189, 193, 196, 198, 201, 203, 205-207, 212, 224, $225,232,233,237,238,242,243,251,258$, $259,261,263,266,271,283,295,296,299$, $300,313,316-318,320,321,323,328,330$, $342,348,349,351,353,354,375-377,381$, $383,385-387,389,392,394,395,398-400$, $403,404,406,417,426,427,440-444,454$, $463,469,472,476,478,481,484,490,498$, $500,501,507,521,531,533,538,539,541$, $545-547,550,552,553,556,558,560,563$ see also Scotland, Wales and Northern Ireland

United States of America, 008, 010, 011, 026, 031-034, 036, 039, 040, 054, 055, 077,
$160-166,179,182-185,188,190,197,200$, $214,215,217,223,241,246,249,250$, 267-270, 272, 274, 277, 279-281, 287-289, $303,312,325,329,332,336-341,343,345$, $347,352,355-358,360,363,364,371,373$, $379,380,390,391,393,396,397,401,402$, $409,410,415,419-422,424,428-434,445$, $450,453,458,460,461,468,471,479,480$, $482,485,488,489,491,492,494,497,499$, $504,505,510-514,518,519,524,527,528$, $532,534,542-544,548,549,554,555,557$, $559,561,562,564$

Unqualified librarians, 113, 142

User education, teaching, 330

User education, training, 508

see also Bibliographic instruction, teaching

USSR, see Union of Soviet Socialist Republics

Videotapes, use in training, 241, 250

Visual resources curatorship (profession), 505

Wales, 207, 317, 318, 320, 444

West Germany, see Germany, Federal Republic

West Indies, see Caribbean

Women librarians, 359, 394

Youth librarianship, see Children's librarianship

Zimbabwe, 229, 509 


\section{LIST OF PERIODICAL TITLE ABBREVIATIONS}

AIB. Boll. Inf.: AIB Bolletino d'Informazione

Akt. Prob. Inf. Dok.: Aktualne Problemy Informacji i Dokumentacji

ALSC News.: Association for Library Service to Children Newsletter Ann. Jap. Soc. Lib. Sci.: Annals of the Japan Society of Library Science APLA Bulletin: Atlantic Provinces Library Association Bulletin Aust. Acad. \& Res. Lib.: Australian Academic and Research Libraries Aust. Coll. Lib.: Australasian College Libraries Aust. Soc. Arch. Bull.: Australian Society of Archivists Bulletin Bull. ASIS: Bulletin of the American Society for Information Science Bull. Med. Lib. Ass.: Bulletin of the Medical Library Association Can. J. Inf. Sci.: Canadian Journal of Information Science Coll. \& Res. Lib.: College and Research Libraries

Coll. \& Res. Lib. News: College and Research Libraries News Cons. Admin. News: Conservation Administration News (CANS) Educ. Lib. Aust.: Education for Librarianship: Australia Foc. Int. \& Comp. Lib.: Focus on International and Comparative Librarianship Inf. \& Lib. Man.: Information and Library Manager Inf. Bull. West. Ass. Map Lib.: Information Bulletin / Western Association of Map Librarians Inf. Proc. \& Man.: Information Processing and Management Inf. Rep. \& Bib.: Information Reports and Bibliographies Int. Coun. Arch. Bull.: International Council on Archives Bulletin Int. J. Inf. Man.: International Journal of Information Management Int. Lib. Rev.: International Library Review

Int. Rec. Man. J.: International Records Management Journal

J. Acad. Lib.: Journal of Academic Librarianship

J. Amer. Soc. Inf. Sci.: Journal of the American Society for Information Science

J. Educ. Lib. \& Inf. Sci.: Journal of Education for Library and Information Science

J. Inf. Sci.: Journal of Information Science

J. Lib. Admin.: Journal of Library Administration

J. Mul. Lib.: Journal of Multicultural Librarianship

J. Soc. Arch.: Journal of the Society of Archivists

J. Syst. Man.: Journal of Systems Management

Lib. Acq. Prac. \& Theory: Library Acquisitions: Practice and Theory

Lib. Admin. \& Man.: Library Administration and Management

Lib. \& Inf. Ass.: Library and Information Assistant

Lib. \& Inf. Res. News.: Library and Information Research News

Lib. \& Inf. Sci. Res.: Library and Information Science Research

Lib. Ass. Rec.: Library Association Record

Lib. Bull. ULLRCC: Libraries Bulletin / University of London Library Resources Coordinating Committee

Lib. Chr. Fell. News.: Librarian's Christian Fellowship Newsletter

Lib. Res. Tech. Serv.: Library Resources and Technical Services

Lib. Sci. Slant Doc.: Library Science with a Slant to Documentation

LLA. Bull.: Louisiana Library Association Bulletin

Mitt. SBPK.: Mitteilungen Staatsbibliothek Preussischer Kulturbesitz

Mitt. Ver. Bib. Land. Nord.: Mitteilungsblatt (Verband der Bibliotheken des Landes Nordrhein-Westfalen) 
Nauch. Teh. Bib. SSR.: Nauchnye i Tehnisheskie Biblioteki SSR

Rech. Dat.: Rechentechnik-Datenverarbeitung

Rec. Man. Bull.: Records Management Bulletin

Rev. Esc. Bib. UFMG.: Revista da Escola de Biblioteconomia da Universidade Federal de Minas Gerais

Rev. AIBDA.: Revista de la Asociación Interamericana de Bibliotecarios y Documentalistas Agrícolas

S. Afr. J. Lib. \& Inf. Sci.: South African Journal of Library and Information Science

Scand. Pub. Lib. Q.: Scandinavian Public Library Quarterly

Sch. Lib. Can.: School Libraries in Canada

Sch. Lib. Med. Q.: School Library Media Quarterly

Scot. Acad. Lib. News.: Scottish Academic Libraries Newsletter

Sov. Bib.: Sovetskoe Bibliotekovendemi

Train. \& Educ. Gp. News.: Training and Education Group. Members' Newsletter

Tud. Mus. Taj.: Tudomanyos es Muszaki Tajekoztatas

Wits. J. Lib. \& Inf. Sci.: Wits Journal of Librarianship and Information Science

Zent. Bib.: Zentralblatt für Bibliothekswesen 